\title{
The Butter-Margarine Controversy and "Two Cultures" at Iowa State College
}

\author{
DAVID L. SEIM
}

DURING WORLD WAR II, economists, college administrators, and citizens of Iowa battled over the purposes of social science. One particular debate in Iowa was a frontline event in a struggle to establish safeguards allowing policy research at public colleges and universities. In a conflict over a proposed policy to temporarily produce less butter, one side declared that economists at Iowa State College (ISC) must limit themselves to advocating policies directly supporting Iowa interests, while an opposing group advocated policy research to win the war (even if that policy temporarily disadvantaged state interests).

Between about 1930 and 1945 an "Ames School" of economics arose at ISC. At the University of Wisconsin, economists traditionally advised government officials on "progressive" policy, but Wisconsin's economists were often criticized for injecting personal values into what should be rigorous and impartial science. ISC's economists wanted policy relevance while escaping such trouble. They avoided Wisconsin-style "collaboration" between academic researchers and government policymakers and took their policy proposals directly to the public. ${ }^{1}$

I am grateful for a research grant from the State Historical Society of Iowa.

1. On the "Wisconsin Idea" (or "Wisconsin School"), see John P. Henderson, "Political Economy and the Service of the State: The University of Wisconsin," in Breaking the Academic Mould: Economists and American Higher Learning in the Nineteenth Century, ed. William J. Barber (Middletown, CT, 1988), 318-39; and THE ANNALS OF IOWA 67 (Winter 2008). (C) The State Historical Society of Iowa, 2008. 
What eventually happened at ISC was that financial donors and college administrators insisted on social science devoid of policy arguments; ISC's social scientists wanted a more realistic standard. The defining moment in the debate took place during 1943 and 1944, when a series of events resulted in a conflict over the possibilities and limitations of policy-oriented social science. ${ }^{2}$

In 1943 Iowa was second in the nation in dairy production. In April of that year, ISC's agricultural economists published a pamphlet titled "Putting Dairying on a War Footing," the fifth installment in the school's Wartime Farm and Food Policy series. The dairying pamphlet analyzed conditions that had resulted in a shortage of dairy products for soldiers. The report recommended, among other solutions, having American households substitute more margarine for butter. ${ }^{3}$

Dairy interests vigorously objected to "Pamphlet No. 5." Dairy industry leaders contacted the college president, applying pressure to retract the pamphlet. After the president gave in, more than half of the faculty in the Department of Economics

Malcolm Rutherford, "Wisconsin Institutionalism: John R. Commons and His Students," Labor History 47 (2006), 161-88. The "Ames School" of economics sought to connect agricultural economics to broader economic issues by employing multiple research methods. See brief mentions in Leonard Silk, The Economists (New York, 1974), 208; and Richard H. Day, "Toward a Dynamical Economic Science: An Autobiographical Reflection," in The Makers of Modern Economics, vol. 4, ed. Arnold Heertje (Cheltenham, UK, 1999), 1-31, esp. p. 3.

2. Debates about objectivity in social science predate the 1940s. See Mary O. Furner, Advocacy and Objectivity: A Crisis in the Professionalization of American Social Science, 1865-1905 (Lexington, KY, 1975); Mark Blaug, "The Formalist Revolution or What Happened to Orthodox Economics after World War II?" in From Classical Economics to the Theory of the Firm: Essays in Honour of D. P. O'Brien, ed. Roger E. Backhouse and John Creedy (Northampton, MA, 1999), 257-80; Mary S. Morgan and Malcolm Rutherford, eds., From Interwar Pluralism to Postwar Neoclassicism (Durham, NC, 1998). An underappreciated factor in the shift toward emphasizing formal approaches in economics was a reaction to the question whether public colleges and universities are "research arms" of private industry - what Jim Hightower once called the "land-grant college complex." See Jim Hightower, Hard Tomatoes, Hard Times: A Report of the Agribusiness Accountability Project on the Failure of America's Land-grant College Complex (Cambridge, MA, 1973).

3. Dairy Record, 4/28/1943, 16; O. H. Brownlee, "Putting Dairying on a War Footing," Wartime Farm and Food Policy Series, no. 5 (Ames, 1943). A copy of the original pamphlet is in file 8/4, Robert E. Buchanan Papers, Special Collections, Iowa State University Library (hereafter cited as Buchanan Files). 


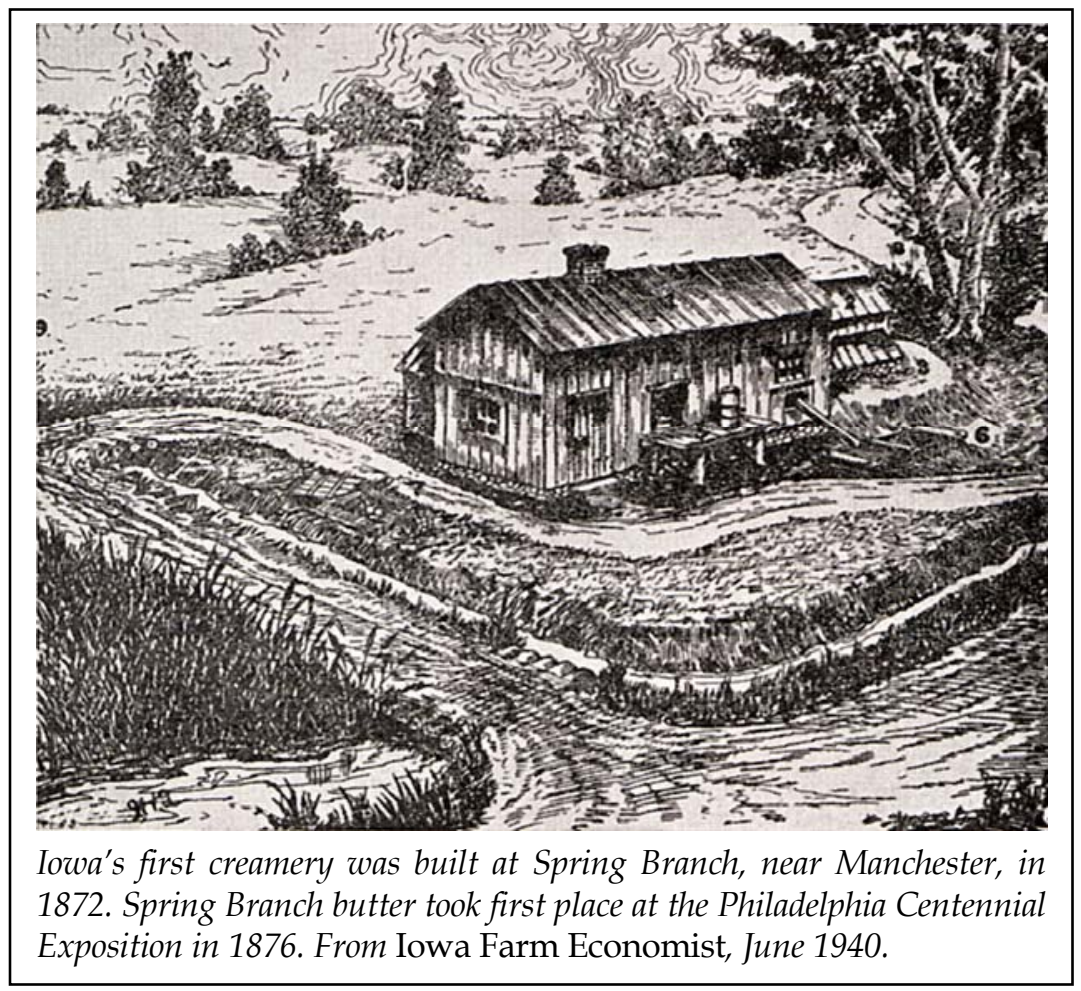

and Sociology eventually resigned in protest, interpreting the retraction as a violation of academic freedom and a development that endangered the social sciences at ISC. National observers wondered whether events in Iowa had implications for social science in general. ${ }^{4}$

The controversy encompassed a variety of views. For some, the central issues were purely scientific questions of taste and nu-

4. Publications covering the butter-margarine controversy include Raymond R. Beneke, "T. W. Schultz and Pamphlet No. 5: The Oleo Margarine War and Academic Freedom," Choices, Summer 1998, 4-8; Minnesota Economics Faculty, "Remembering Oz Brownlee (Oz and Oleomargarine)," Minnesota Department of Economics Graduate Alumni Newsletter, Fall 1994, 1-2. Older summaries include Chester Kerr, A Report on American University Presses (Washington, DC, 1949), 68; Charles M. Hardin, Freedom in Agricultural Education (Chicago, 1955), 119-25; Earle Ross, The Land-Grant Idea at Iowa State College: A Centennial Trial Balance, 1858-1958 (Ames, 1958), 217-20. The controversy is mentioned briefly in Dorothy Schweider, "Iowa State at Mid-Century: The Friley and Hilton Years," in A Sesquicentennial History of Iowa State University: Tradition and Transformation, ed. Dorothy Schweider and Gretchen Van Houton (Ames, 2007), 43-44. 
tritional equivalence between butter and margarine. For others, the prevailing concern was a college administration declaring that ISC's first purpose was to serve Iowa's special interests. Some Iowa citizens emphasized the need to prevent social science research methods from becoming too "soft." Many participants in the controversy interpreted the event as a test case for the validity of allowing social scientists at public institutions to advocate public policy.

THE ROAD TO CONFLICT over Pamphlet No. 5 began when Theodore W. Schultz joined the Department of Economics and Sociology at ISC in 1930. Quickly establishing a reputation for willingness to confront what he called "vested interests," Schultz focused on the ways that powerful interest groups distort economic efficiency in such areas as tariff policy, the tax system, and agricultural production. To help understand problems created by special interests during the Great Depression, in 1932 Schultz recommended a pamphlet series for public readership to be titled Agricultural Emergency in Iowa. ${ }^{5}$

Upon his appointment as acting head of agricultural economics at ISC in fall 1932, Schultz met with Agricultural Experiment Station director Robert Buchanan to push for the envisioned pamphlets. Schultz explained that the school's agricultural econ-

5. Little is published about Schultz during his ISC years. Schultz came to ISC with a Ph.D. in agricultural economics from the University of Wisconsin (1930). He soon published a series of papers on policy concerns. He took a position, for example, against the effects of a generally high import tariff, especially on the nation's ability to export agricultural products. Schultz's ideas were respected by Henry A. Wallace, editor of Wallaces' Farmer and Iowa Homestead, who saw Schultz as "a remarkable young man because he had the courage to tell the truth about the tariff to an Iowa audience." Henry A. Wallace, "Odds and Ends," Wallace's Farmer and Iowa Homestead, 3/5/1932, 5. Schultz established a reputation for not backing down from unpopular messages. In 1935 he argued that the "realistic view of the facts forces us to the conclusion, whether we wish it or not, that American agriculture is still dependent upon foreign buyers." T. W. Schultz, "Vanishing Farm Markets and Our World Trade," World Affairs Pamphlet no. 11 (Boston, 1935), 23, 26. For brief bits of information on Schultz's ISC years, see D. Gale Johnson, "Theodore William Schultz, 1902-1998," National Academy of Sciences, Biographical Memoirs, vol. 77 (Washington, DC, 1999), 302-17; and Mary Jean Bowman, "T. W. Schultz: Scholar and Statesman," in Contemporary Economists in Perspective, ed. Henry W. Spiegel and Warren J. Samuels, 2 vols. (Greenwich, CT, 1984), 1A: 103-21. 
omists were interested in educating citizens on contemporary farm policies. Buchanan agreed that, as a land-grant institution, ISC had obligations in "Extension Service," and he approved the pamphlets. ${ }^{6}$ Once produced, the series of ten pamphlets boosted the reputation of ISC's economists. Schultz then met with ISC President Raymond Hughes to suggest that the time was right to hire new faculty to make the Department of Economics and Sociology one of the best in the nation. Hughes was persuaded, generous funding was provided, and new hires were made. ${ }^{7}$

Schultz became permanent head of the Department of Economics and Sociology early in 1935 . He recruited rising stars to join a group soon known as the "Ames School" of economics. Before long ISC's economists earned national recognition for their work in defining the place of social science at a land-grant institution. Their goal was to communicate research findings and their likely implications to the public. Schultz encouraged economists in his department to find value in many research methods, including theory, empiricism, and historical analysis, as well as such allied fields as political science, legal studies, social psychology, and social anthropology. Such methodological openness was needed to fully evaluate real world problems and to counteract the economic inefficiency created by special interests. In 1941 Schultz concluded, "The future demand for professional and scientific workers in the rural social science fields will be affected favorably by the fact that workers in these fields are not strait jacketed by a series of rigid job descriptions." 8

6. “T. W. Schultz Appointed Head of Economics Work," Summer Quarter News, Iowa State College, 6/27/1935, 1, in file 14/2, Theodore W. Schultz Papers, Special Collections, Iowa State University Library (hereafter cited as Schultz Files-ISC). On the Extension Service at ISC, see Dorothy Schwieder, "The Iowa State College Cooperative Extension Service through Two World Wars," Agricultural History 64 (1990), 219-30; and Hightower, Hard Tomatoes, Hard Times.

7. Iowa State College Press produced 10 pamphlets between November 1932 and March 1933 under the title Agricultural Emergency in Iowa. Seven ISC economists wrote the pamphlets, which were submitted directly to the press by the authors and were published as submitted.

8. "Schultz Appointed Head"; Theodore W. Schultz, Training and Recruiting of Personnel in the Rural Social Sciences (Washington, DC, 1941), 6-8, 10. 
The response to a 1937 article by Margaret Reid, published in the department's magazine for public readership, Iowa Farm Economist, tested Schultz's belief that social scientists at an agricultural college were no longer limited by constraining job descriptions. In "Taxing the Chain Store," Reid argued that any national policy of increased taxes on chain stores would disproportionately affect small Iowa communities. In response to Reid's analysis, the U.S. Post Office decided, three years later, to bill ISC's Extension Service for postage due on the magazine installment containing the article. (The government was to pay mailing costs only if all contents fit the proper purview of Extension Service research.) The Office of the Postmaster General ruled that Reid's article "is not regarded as relating exclusively to 'cooperative agricultural extension work.'" The ruling suggested a potential limitation on government-sponsored economic analysis. ${ }^{9}$

ISC Agricultural Experiment Station director Buchanan and Extension Service director Ralph K. Bliss disagreed. Determining that there was "a principle involved," they weighed possible responses. "The educational purpose of this article," they argued in their letter to Washington, "was to give the farm people in the State of Iowa an awareness of some of the important issues" in U.S. policy. Specifically, "the prevailing type of taxation is likely to bear heavily on stores in the smaller towns." Buchanan and Bliss believed that it was appropriate to ensure "that farm people be enlightened on all matters pertaining to their interest." When the Post Office rejected ISC's appeal, Buchanan went to Washington, where he resolved the matter in ISC's favor. ${ }^{10}$

When Schultz took aim at southern special interests during an NBC radio broadcast on "Farmers and Victory" in early 1943, saying "it would not hurt the war effort one iota if we dumped all the 1943 cotton crop into the Gulf of Mexico," a flood of let-

9. Margaret G. Reid, "Taxing the Chain Store," Iowa Farm Economist 3 (April 1937), 8-10; Third Assistant Postmaster General to Postmaster, Ames, 10/7/ 1940, Buchanan Files 10/5.

10. R. K. Bliss to R. E. Buchanan et al., 10/30/1940; W. W. Wilcox to R. K. Bliss, 11/6/1940; R. K. Bliss and R. E. Buchanan to Third Assistant Postmaster General, 11/30/1940; Ramsey S. Bloch, Third Assistant Postmaster General, to R. K. Bliss, 12/7/1940; R. E. Buchanan to Dean H. P. Rusk, 12/19/1940, all in Buchanan Files 10/5 (quotations are from Bliss and Buchanan's 11/30 letter). 
ters from Southern politicians and business leaders depicted Schultz as a loose cannon. ISC president Charles E. Friley, previously a dean at Texas A\&M, managed to stay above the fray by distancing himself from Schultz and by allowing simply that the situation was complex. ${ }^{11}$

IN RECOGNITION of the ISC economists' growing reputation for publicly oriented social science policy research, in October 1942 U.S. Secretary of Agriculture Claude Wickard asked them to prepare food policy analysis for a national readership. With Director Buchanan's approval, ISC agreed to develop policy pamphlets for distribution. ${ }^{12}$ In its agreement with the U.S. Department of Agriculture (USDA), ISC requested a grant from the Rockefeller Foundation. In the request Schultz emphasized the pressing importance of "a study of governmental policies affecting production and distribution of food." He assured the foundation that the project had been cleared "with President Charles E. Friley and with members of the administrative staff at ISC," and was encouraged by Secretary Wickard's "urgent" belief in "the need for critical appraisals made by persons outside of government, evaluations which will point out the merits and limitations of current policies and programs." Wickard, Friley, and Buchanan provided endorsement letters. Friley, claiming that he had personally "gone over" the research plans, assured the foundation of his "full endorsement." 13

11. Letters and other materials relating to the "cotton controversy" are in file 29/15, Theodore W. Schultz Papers, Special Collections, University of Chicago Library (hereafter cited as Schultz Files-Chicago); and Schultz Files-ISC 14/2. See also C. E. Friley to L. P. Gabbard, 3/31/1943, file 9/27, Charles E. Friley Papers, Special Collections, Iowa State University Library (hereafter cited as Friley Files).

12. Schultz's summary of events during the initial stages of the project is in T. W. Schultz, "Outline of a Presentation before the Board of Education on 'Studies of Government Food Policy,', 6/22/1943, Buchanan Files 8/1, Friley Files 6/9. The USDA's show of respect for ISC would not have been surprising. ISC economists were known to be at work on agricultural price studies, and the college had a tradition of producing agriculturists who became national leaders: "Tama Jim" Wilson, Henry C. Wallace, and Henry A. Wallace, for example.

13. T. W. Schultz to J. H. Willits, 10/1/1942; Claude Wickard to J. H. Willits, 10/8/1942; C. E. Friley to J. H. Willits, 10/10/1942, folder 39, series 218S, RG 1.1, Rockefeller Archives Center, Rockefeller Foundation, Sleepy Hollow, New 


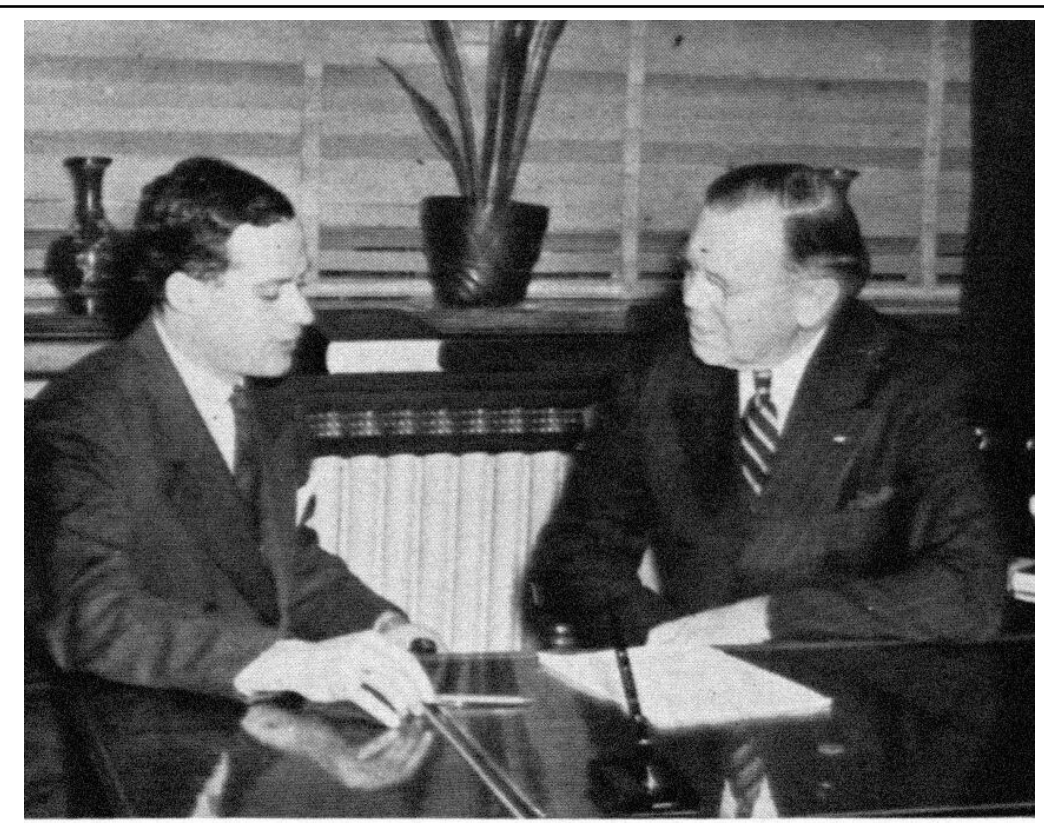

In keeping with his ongoing support for the war effort, ISC President Friley (right) conferred with Undersecretary of the Navy Gerard Swope. From the ISC yearbook, The Bomb.

The ensuing Rockefeller Foundation grant stipulated that all money be administered by Schultz and that all funds revert to the foundation should Schultz leave ISC. The foundation hoped that the proposed study would result in "recommendations as to food production, distribution and consumption policies." Joseph Willits, the director of the Rockefeller Foundation's Social Science Division, wrote to Secretary Wickard:

This is a very interesting relation between the Department [of Agriculture] on the one hand and Professor Schultz on the other. It is the kind that seems to me to be one of the constructive relations between a government department and a social scientist, but the

York (hereafter cited as RAC-RF, with all such citations citing this same folder, series, and record group unless otherwise noted); R. E. Buchanan, "Recommendation for Acceptance of Gift Funds by the Iowa Agricultural Experiment Station," 10/20/1942, Friley Files 6/9. Additional correspondence between Schultz and Willits is in Schultz Files-Chicago 29/23. See also correspondence between C. E. Friley and J. H. Willits, Friley Files 6/9. 
kind that is possible only where, as in this case, there is a public official statesmanlike enough to welcome and seek out independent and competent outside criticism and a social scientist who is sympathetic with the problems of the administration and also competent and objective. The whole arrangement is a very reassuring one to me as a citizen; I hope it works out well. ${ }^{14}$

Clearly, by 1942, ISC's economists had established a reputation among national leaders for competent, detached professionalism in studying policy matters.

Preparation of the pamphlets began as four ISC economists formed an "economics review committee" to identify food policy problems and distribute draft manuscripts to economists and government officials. The committee established that each pamphlet must pass a minimum of six rounds of revisions and that pamphlets passing all rounds would be certified with the indicia, "Iowa State College Press." Such official status was important, Schultz explained, because "by publishing we make ourselves professionally accountable, which is an essential step in work of this kind." By December 1942 a series of 15 pamphlets was outlined and ready to begin. ${ }^{15}$

14. Joseph Willits to Claude Wickard, 10/16/1942, RAC-RF; Joseph Willits to T. W. Schultz, 10/16/1942, ibid.; Schultz to Willits, 10/17/1942, ibid. Originally, the $\$ 10,000$ grant was for a period ending June 30,1943, but was later extended. "Resolved RF 42091," 10/16/1942, ibid.; "Grant Extension," 6/10/ 1943, ibid. President Friley gratefully accepted the foundation's grant and reiterated his knowledge of what the project aimed to accomplish. C. E. Friley to Norma S. Thompson (Joseph Willits's secretary), 11/2/1942, ibid.

15. T. W. Schultz to Joseph Willits, 12/3/1942, RAC-RF. Schultz invited Willits to visit with the social science seminar at ISC to "probe with us the nature of the more fundamental research underway in the social science fields and its merits and limitations' as seen from your point of vantage?" Willits accepted the invitation, but hesitated to "make any speeches." Schultz to Willits, 1/5/ 1943, ibid.; Willits to Schultz, 1/8/1943, ibid.; Secretary Paine (Willits's secretary) to Schultz, 1/20/1943, ibid.; Schultz to Willits, 1/29/1943, ibid. Willits in fact visited in February 1943 and recorded a lofty view of the ISC economists. Yet he worried that "they would break up if Schultz left," although Schultz's recent decline of job offers from the University of Chicago and the University of California suggested that "he is likely to stick and cares more for the group and the work close to his own problem there than he does for the kudos and money the other places offer." "Memoranda of Interview," JHW with Theodore W. Schultz, 2/11-12/1943, ibid. By late February Schultz reported that drafts of the first three pamphlets (dealing with the overall framework of food production) were well received by reviewers, and that "the dairy pamphlet is 
The first pamphlet through the review process was Margaret Reid's "Food Strategy," published in January 1943. Reid set an overall tone for the series by proclaiming "that shortage of many foods will become greater" and that "wise strategy calls for action of several types": use of national and international agencies; management of food stockpiles; rationing by civilians; educational programs; and squeezing the greatest economy from existing resources. Such management strategies would be analyzed in upcoming pamphlets intended especially for farmers, educators, and politicians. 16

More pamphlets quickly followed. In early February came Schultz's pamphlet, "Farm Prices for Food Production," and the next month saw "Manpower in Agriculture" and "Food Rationing and Morale." O. H. Brownlee's 35-page pamphlet, "Putting Dairying on a War Footing," passed through the review process and into print the first week of April 1943. The author, a doctoral student in economics, advocated making more milk products available to soldiers, generally by rationing and shifting milk to its most productive uses. One specific proposal was that American households use more margarine instead of butter. ${ }^{17}$

also far along." Schultz to Willits, 2/25/1943, ibid. See also Willits to Schultz, 3/5/1943, ibid.; and Schultz to Willits, 4/14/1943, ibid.

16. Margaret G. Reid, "Food Policy," Wartime Farm and Food Policy Series, no. 1 (Ames, 1943), 1-2. Reid's pamphlet, published on January 21, served as a broad overview of the issues to be dealt with throughout the series.

17. Theodore W. Schultz, "Farm Prices for Food Production" (no. 2); Rainer Schickele, "Manpower in Agriculture" (no. 3); C. Arnold Anderson, "Food Rationing and Morale" (no. 4); O. H. Brownlee, "Putting Dairying on a War Footing" (no. 5). Six more pamphlets ended up being published: Geoffrey Shepherd, "Commodity Loans and Price Floors for Farm Products" (no. 6); Arthur C. Bunce, "Using Our Soils for War Production" (no. 7); Mary Jean Bowman and Albert Gailord Hart, "Food Management and Inflation" (no. 8); William G. Murray, "Land Boom Controls" (no. 9); D. Gale Johnson and O. H. Brownlee, "Food Subsidies and Inflation Control" (no. 10); and Geoffrey Shepherd, "Agricultural Prices After the War" (no. 11). All of the pamphlets were fairly substantial documents, ranging between 27 and 50 pages in length. Brownlee's Pamphlet no. 5 went to press after Schultz and others had evaluated the report on which it was based, interpreted it as solid, and circulated it to academic and government economists. Commentators approved of Brownlee's broad recommendation that milk be shifted to its most productive uses. The economics department then admitted it into the series, and 1,000 copies were printed. See O. H. Brownlee, "A Biography of Pamphlet No. 5 by the Author," Oct. 1943, Schultz Files-Chicago 29/23. 
Adverse reaction to Brownlee's "Pamphlet No. 5" was prompt and vociferous, especially from representatives of Iowa's dairy industry. They especially objected to the recommendation that Americans use more margarine and Brownlee's claim that "margarine compares favorably with butter both in nutritive value and palatability." Their objection was consistent with the dairy industry's declared goal to achieve nothing short of "complete extermination of oleomargarine." 18

Dairy leaders filed complaints directly with President Friley. An attorney for dairy interests identified the pamphlet as an infraction against farmers as taxpayers. The Iowa dairy industry stood betrayed

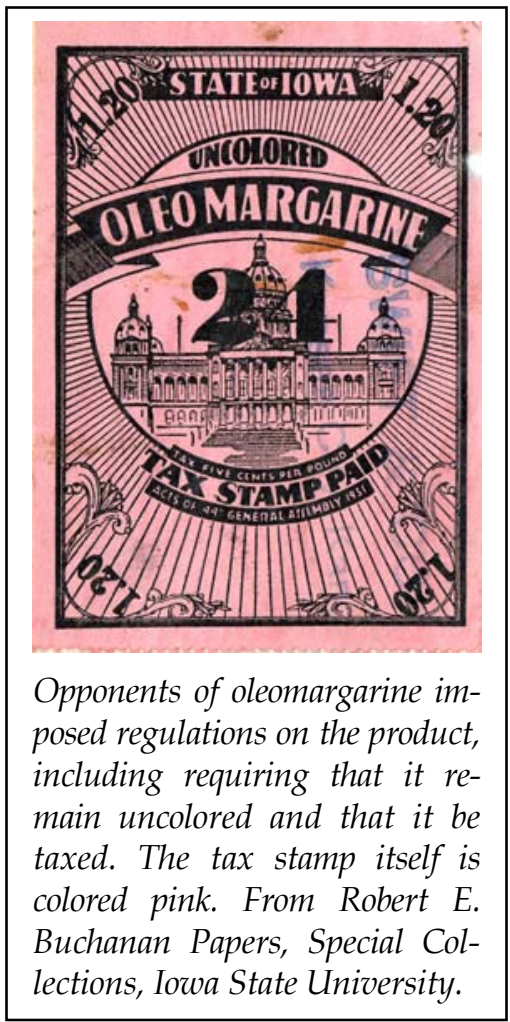
"like Caesar," wrote Addison Parker, "stabbed in its own house by its friends." No record exists of any response by Friley to Parker or any other early complainant. In fact, dairy representatives consistently found Friley unavailable for meetings. Failing to achieve satisfaction from ISC economists or administrators, dairy representatives took their complaints to the press. ${ }^{19}$

18. Brownlee, "Putting Dairying on a War Footing," 30; "Call for a Conference," Dairy Record, 6/18/1941, 10-11; "Will Butter Win the Peace?" Fortune Magazine, Nov. 1944, 133; Des Moines Register, 6/13/1943. The sale of oleomargarine was illegal in some states, and in others the product needed to be dyed pink or green. In Iowa, oleomargarine could not be sold colored yellow, although capsules of yellow dye were sometimes allowed so people could color their own. See "Iowa and Margarine," Newsweek, 6/14/1943, 72, 74. For more on the history of "bull" or "bogus" butter and a variety of reactionary "margarine laws," see S. F. Riepma, The Story of Margarine (Washington, DC, 1970), esp. 108-33.

19. Addison M. Parker to Charles E. Friley, 5/6/1943, Schultz Files-Chicago $29 / 23$. 
On April 28 the Dairy Record (St. Paul, MN) published a bitter editorial declaring Pamphlet No. 5 a "repetitious peroration" and a "dud." ISC had thrown "a gratuitous slap at the creamery industry." The economist authoring the pamphlet was a "sadistic" person who "has a false notion that he pursues a calling that is, of itself, a science. The very fact that the author . . . fails to take cognizance of the economic importance of the butter industry to the state he is supposed to serve seems to indicate that, in his search for the profound, he has forgotten the simplest definition of his vocation." The author, like all economists, must be an "unstable" person troubled by an "inferiority complex," who during college days was "unwilling or unable to provide the concentration needed to master the exact sciences." 20

In early May the Creamery Journal (Waterloo, IA) chimed in, declaring the pamphlet "an uncalled for outburst." The journal reported that "a number of dairy leaders were on their way to the college to confer with officials." The Des Moines Register also paid attention; the Iowa Association of Local Creameries told it that "dairy farmers will be satisfied with nothing less than a recall of the pamphlet, denial of faculty responsibility for it, and removal from the faculty of Iowa State College of its authors as self-convicted incompetents." Julius Bruner, president of the association, complained that the pamphlet was sanctioned by the same institution "that the dairy farmer willingly and liberally has taxed himself to maintain and support over a long period of years." The Dairy Record returned to the subject in mid-May with an editorial reporting that "dairymen, refusing to be placated by other college representatives," had pressed for a meeting with Friley. ${ }^{21}$

20. "Iowa Issues a Pamphlet," Dairy Record, 4/28/1943, 16. Possibly the earliest articles outside of Iowa were "Dairy Industry Facing Butter Curb Problem," Chicago Journal of Commerce, 5/17/1943 (copy in Schultz Files-Chicago 29/23); and "Iowa Booklet Stirs Storm in Dairy Industry," Chicago Daily News, 5/25/1943.

21. "Iowa Dairy Interests Incensed at College Economists View," Creamery Journal, May 1943, 26; "State College Oleo Booklet Raises Storm," Des Moines Register, 5/15/1943; "Iowa Groups Wrathy," Dairy Record, 5/19/1943, 7, 23. The Iowa State Daily Student, 5/18/1943, saw the dairy industry move as a "hysterical attack" designed "to oppress those whose interests lie only in relaying the truth." The next day's editorial stated that science should advance on the basis of the truth or falsity of findings alone. 


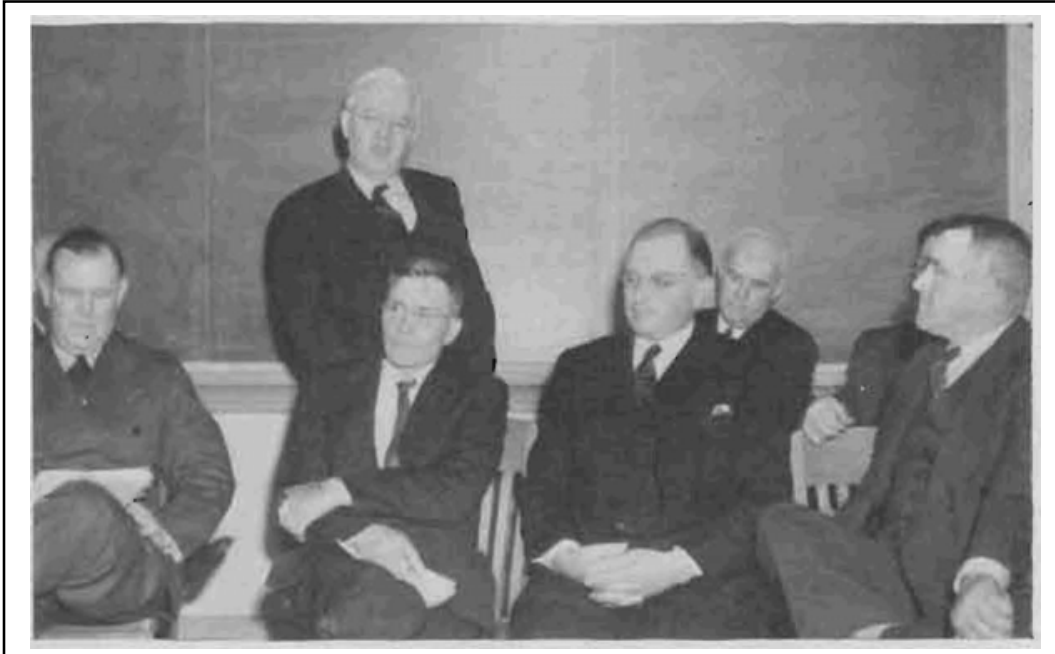

Pictured left to right are ISC President Charles E. Friley and the six dairy representatives on the Joint Committee: Clem O'Neil (standing), secretary of the Iowa Milk Dealers Association; Julius Bruner, president of the Iowa Association of Local Creameries; Clarence Nielson, Iowa Butter Manufacturers Association; P. W. Crowley, Association of Ice Cream Manufacturers of Iowa; Ralph Bartlett (hidden), Iowa Creamery Operators Association; Scott Ellis, Iowa Dairy Industry Commission. O'Neil was later replaced by A. N. Heggen, Iowa Cooperative Milk Producers Association. Photo taken on May 19, 1943, at Ames; from Creamery Journal, June 1943.

On May 19 an estimated 125 dairy and creamery representatives met with ISC administrators. Friley's opening remarks focused on one question: Are there any inaccurate facts in the pamphlet? The only debatable issues would be "the legitimacy of the facts and perhaps the form and clarity of the phraseology used in stating those facts." "The right of the institution to publish facts is not a debatable question in this nation. Otherwise, the entire framework of academic freedom, and even of freedom of speech, is gone, and the usefulness of the institution is at an end." After Schultz summarized USDA objectives for the pamphlet series as a whole, dairy representatives took the floor to voice their objections. Francis Johnson, president of the Iowa Farm Bureau Federation, spoke the longest. He drew attention to farming interests "alarmed over the apparent tendency to 
make over Iowa State College into a tax-supported blueprint of Harvard University." ISC is different from Harvard by not being a "free-lance" institution. ISC has no right to risk making "impractical suggestions or recommendations" on policy matters. "The true test of the value of most research on matters of public policy," Johnson pronounced, "is determined by the eventual acceptance and use of the recommendations. The college cannot justify its existence on the basis of mere 'irrational value.'" 22 The central question was already clear: What kinds of policy research by social scientists would be allowed at a taxpayer-supported college?

Friley ended the meeting by ordering appointment of two committees: a five-member "Special Committee" (including no one from agricultural economics), whose task was to evaluate the pamphlet and report directly to Friley; and a "Joint Committee" of six dairy and six faculty representatives, with the task to review Pamphlet No. 5 "paragraph by paragraph to determine by objective evidence the accuracy of the contents." Friley named his assistant, George Godfrey, to head the Special Committee, and Dean of Agriculture Henry H. Kildee to chair the Joint Committee. The two committees had until July 12 to report their findings. ${ }^{23}$

22. C. E. Friley, "Statement, Dairy Industry Conference, by Charles E. Friley, President," 5/19/1943, Friley Files 2/27; Des Moines Register, 5/20/1943; "Comment," Creamery Journal, June 1943, 14, 26; "Right to Analyze Data Should Never Be Denied-Friley," 20 May 1943, Information Service, Iowa State College, Buchanan Files 8/14. News releases from the Information Service are in an archived collection titled "Daily News" (also known as the "Blue Sheet Collection"), Special Collections, Iowa State University Library. Many of Friley's talking points were prepared by Buchanan. Buchanan to Friley, 5/17/ 1943, Buchanan Files 8a/3, Schultz Files-Chicago 29/17.

23. Friley assigned B. H. Thomas (professor of animal husbandry), B. W. Hammer (professor of dairy industry), C. Y. Cannon (professor of dairy industry), and Pearl Swanson (professor of foods and nutrition) to serve with Godfrey on the "Special Committee." Des Moines Register, 5/20/1943. The six faculty representatives on the Joint Committee (with Kildee as non-voting chair) were R. E. Buchanan (director of the Agricultural Station); C.A. Iverson (head of the Department of Dairy Industry); W. G. Murray (Department of Economics and Sociology); P. Mabel Nelson (head of the Department of Food and Nutrition); T. W. Schultz (head of the Department of Economics and Sociology); and G. S. Shepherd (Department of Economics and Sociology). Charles E. Friley to R. E. Buchanan et al., 6/1/1943, Buchanan Files 8a/3. 
The weeks that followed were anything but quiet. While Iowa Farm Bureau president Johnson launched an attack on another objectionable pamphlet, "Food Management and Inflation," by Mary Jean Bowman and Albert G. Hart, Schultz continued working to establish a place for unbiased policy analysis at ISC. ${ }^{24}$ Still wanting to believe that ISC "is outstanding in its policy of supporting research findings, pressure or no pressure" (as he wrote a friend), Schultz arranged a late May meeting with President Friley. Schultz provided a general critique of the role of ISC professors as "trustee[s] of the public." In particular he cited the case of an ISC professor exposed for accepting employment to write ads for a cattle breed association's advertising campaign. "Can a professor under arrangements of this nature stay wholly impartial, unbiased and objective?" Schultz asked Friley. "Will not other special interest groups, seeing arrangements of this type, quite properly come to expect similar personal services on their behalf?" Schultz believed that any such ties to special interests necessarily led to a loss of public confidence in research findings at ISC. ${ }^{25}$

Pamphlet No. 5-in no way captive to special interestsfound warm reception in at least some quarters. An excited Carl Hamilton, assistant to the U.S. Secretary of Agriculture-and a proud ISC alum-reported to Friley that the pamphlet had re-

24. Des Moines Register, 5/23/1943. The American Farm Bureau supported the Iowa Farm Bureau's attempt to push ISC to dismiss the faculty members involved. "Iowa Booklet Stirs Storm," American Farm Bureau Federation, Official News Letter, 6/1/1943, 4. On the other hand, Iowa Farmers Union president Donald Van Fleet accused Johnson of launching a "witch hunt . . . to smother free thought at our state schools." Des Moines Register, 5/25/1943. See the ensuing exchange of letters to the editor, ibid., 6/2/1943, 6/5/1943, 6/16/1943.

25. T. W. Schultz to Trayer S. Anderson, 5/18/1943, Schultz Files-Chicago 29/22; Schultz to Friley, 5/28/1943, Friley Files 10/48. See also Trayer S. Anderson to Schultz, 5/15/1943, Schultz Files-Chicago 29/22, where Schultz's friend, University of Iowa history professor Trayer Anderson, writes that the need to confront constant pressures by dairy interests "is a vital matter for the integrity of our institutions of higher education." In his correspondence with Anderson, Schultz wrote of his desire to remain at ISC for the long term even though he had been offered a job at the University of Chicago. Schultz explained that he had declined the job offer mainly because the ISC administration was outstanding in allowing controversial research. Schultz specifically cited the administration's support against "protests" by dairy groups "that have been expressed during the years I have been here." 
ceived "considerable and favorable comment" in Washington. The USDA had been waiting for a reputable institution to have the courage to say "the things Iowa State College has now said." People in Washington were grateful to ISC, and Friley should interpret all the public attention as an opportunity for ISC to join an elite rank of research institutions in the social sciences. Hamilton even recommended that Friley request more projects along similar lines. ${ }^{26}$ Harvard agricultural economist John D. Black, a friend of Schultz, informed Willits at the Rockefeller Foundation that Brownlee had produced "a very good pamphlet," a pamphlet benefiting from extensive commentary by a reputable group of draft readers. ${ }^{27}$ Willits joined in thinking highly of the pamphlet, yet was also growing concerned about the reaction unfolding in Iowa. He asked Schultz to keep him apprised of the situation. ${ }^{28}$

Iowa newspapers began debating whether ISC's social scientists should be permitted to make policy arguments. An editorial in the Des Moines Register framed some of the issues. Expressing "devotion to 'the scientific approach"' to social research, the Register's editorial board opined that "as a democratic people we are trying to thrash the thing out, in the light of all the facts and interpretations that we can get, so as to arrive eventually at the right answer." Yet the editorial added that "the issue is not one of the right and duty of professors to try to serve the public

26. Carl Hamilton to Charles E. Friley, 6/12/1943, Buchanan Files 8a/16. Hamilton suggested that Friley tell Schultz that his new series of bulletins "is one of the most significant things being done in any land-grant college at the present time. But you must plan to expand this series into something that will bring home to Iowans the utterly staggering new responsibilities which must be theirs in the post-war world."

27. John D. Black to J. H. Willits, 5/12/1943, RAC-RF. Another positive reaction by an important person outside of Iowa came from L. J. Norton, professor of Farm Management Extension at the University of Illinois, who described Pamphlet No. 5 as "a rather forward looking analysis," published in the face of the "masses of farmers and other people [who] understand only one language when it comes to economic matters." L. J. Norton to T. W. Schultz, 6/1/1943, Buchanan Files 8a/13.

28. J. H. Willits to T. W. Schultz, 5/18/1943, RAC-RF. Schultz provided Willits a copy of Friley's "Statement," as well as clippings from the Iowa City PressCitizen (5/20/1943), Mason City Globe-Gazette (5/20/1943), and Des Moines Register (5/21/1943). Schultz to Willits, 5/25/ 1943, RAC-RF. 


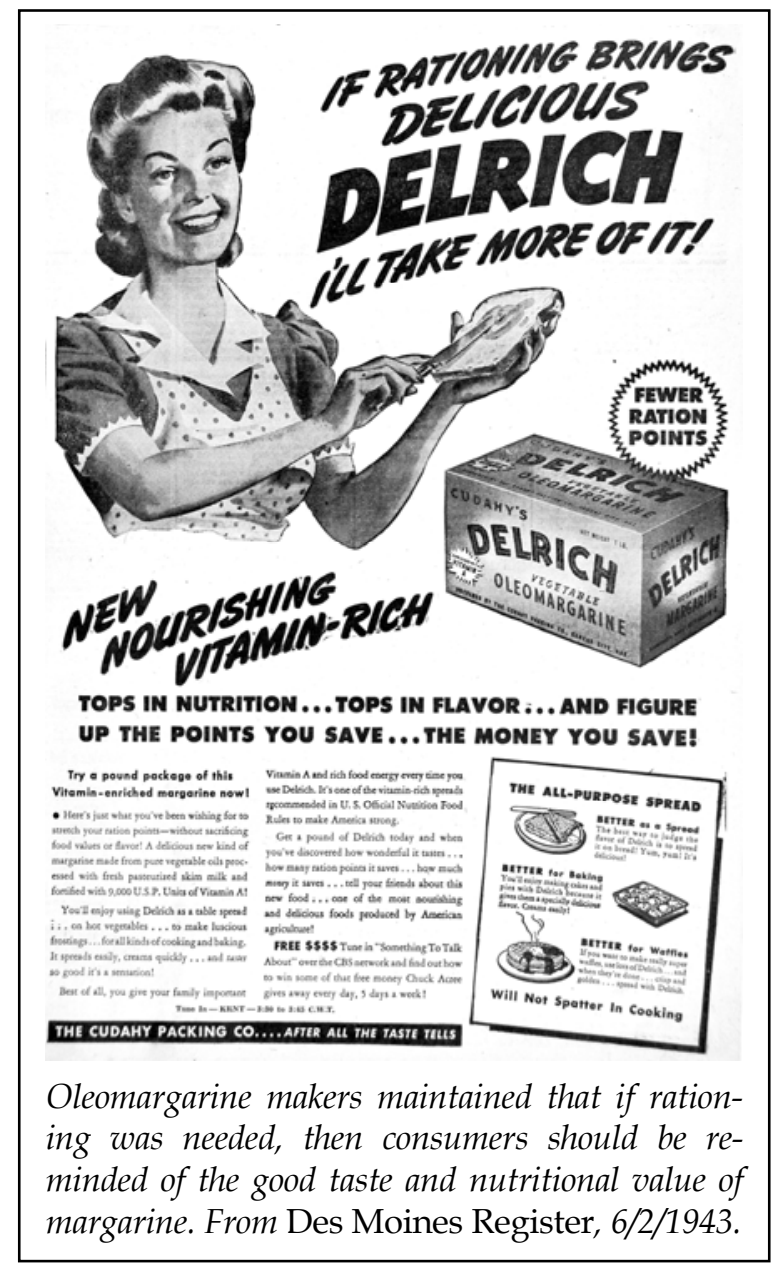

interest." Numerous subsequent letters and editorials revealed complex thinking on both sides of the issue. ${ }^{29}$

The Register also published excerpts from Pamphlet No. 5, to which dairy interests responded with a full-page advertisement sponsored by the American Dairy Association (ADA). The

29. Des Moines Register, 5/21/1943, 5/23/1943, 5/26/1943, 5/27/1943, 5/31/ 1943, 6/11/1943, 7/11/1943, 7/15/1943, 9/2/1943, 9/9/1943, 9/26/1943, 9/29/1943, 10/1/1943. At least twice the Register gathered published opinion from other newspapers around the state. Overall, those expressing the prodairy view seem to outnumber those supporting the economics department. Des Moines Register, 5/31/1943, 10/9/1943. 


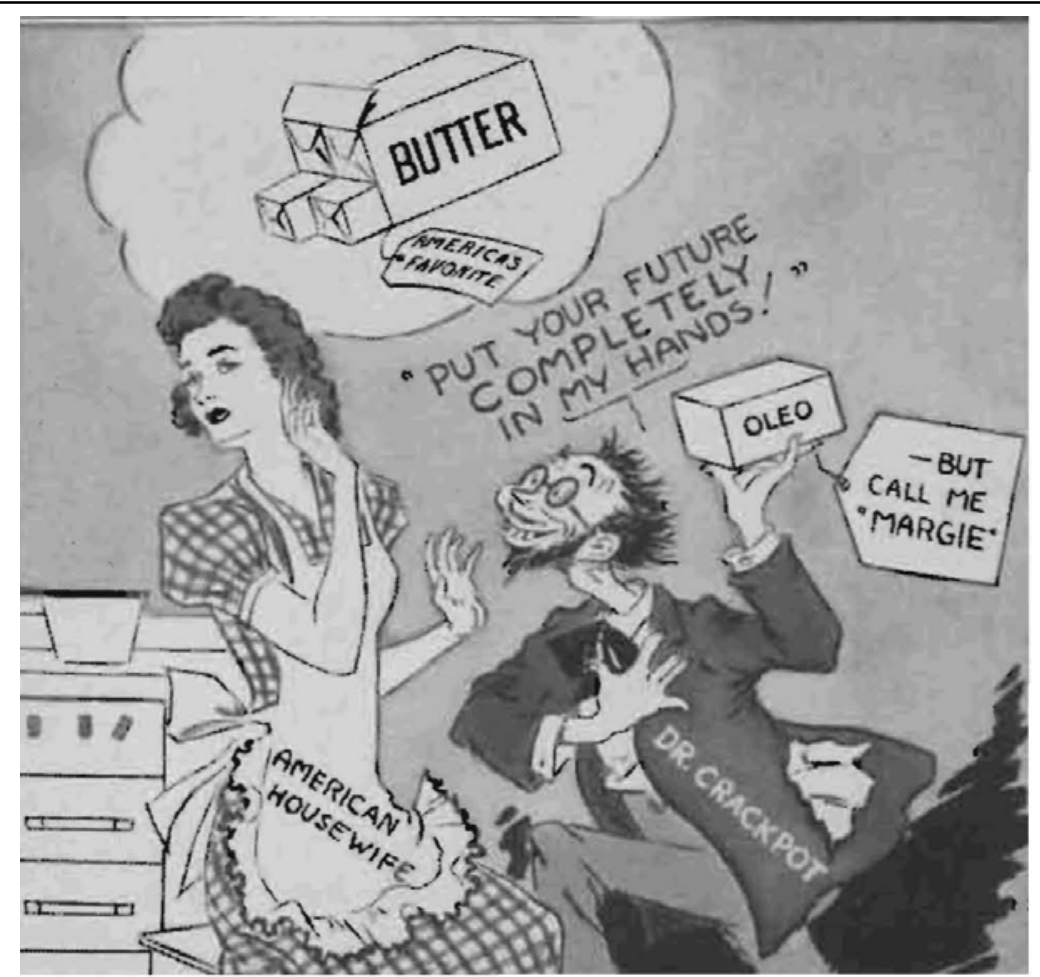

The dairy industry depicted the American housewife as doing all she could to resist the mad science that must be behind the duping of as many margarine users as there already were. From Creamery Journal, July 1943.

ad accused ISC economists of proposing "that the housewives of America be denied butter and be forced to accept a product they have refused on its own merits." The ADA even depicted ISC as subverting the war effort by "taking a stand against the Government's Wartime Food Production Program." The ADA claimed that no fewer than "five million dairy farmers are shocked at the rumpus created by the much-discussed Pamphlet No. 5," which "rocks the very foundation of diversified farming" and "challenges the dairy farmer's way of life." Iowa dairy representatives, following immediately in the slipstream of the ADA's advertisement, passed a formal resolution declaring that the pamphlet "jeopardizes the national war food program" and "has done untold injury to a basic industry which 
means an annual income to the state of more than 100 million dollars per year." 30

The Iowa Board of Education, which oversaw the state's educational institutions, promptly convened an emergency meeting exclusively to discuss Pamphlet No. 5. Schultz was invited to describe the policy project, including the dairy pamphlet. According to one member of the board, Schultz said that "the trouble with the [dairy] pamphlet was that the material had been boiled down and boiled down to get into smaller compass until the array of facts, supporting the conclusion announced in the pamphlet, had been pretty well boiled out of it." When asked if any conclusions might be changed once all supporting facts were reintroduced, Schultz's reply was "absolutely no." 31

WHILE PUBLIC OPINION was in turmoil around the state, the Special Committee and the Joint Committee were hard at work. The Special Committee completed its report for Friley on June 14. That same day (prior to meeting with Friley) the committee met with Brownlee, Schultz, and Reid. The three economists identified some possible errors in the committee's analysis and explained that the committee had overlooked the cautious realism of Brownlee's recommendations. For example, whereas the pamphlet recommended redirecting resources whenever feasible, the committee seemed to be reading the pamphlet as arguing that nearly all resources must be redirected. Still, Schultz, conceding the need for "major clarification," especially to document the pamphlet's argument "a good deal more than it has been," visited Friley's office the next day to recommend that ISC take the initiative in revising the pamphlet. ${ }^{32}$

30. Des Moines Register, 6/3/1943, 6/15/1943, 6/16/1943. See also Creamery Journal, July 1943, 22, 27. Iowa dairy interests even suggested that Pamphlet No. 5 was somehow in violation of the rules of the Rockefeller Foundation Gift Fund. Law Office of Harry J. Albrecht to R. E. Buchanan, 5/29/1943; R. E. Buchanan to Law Office of Harry J. Albrecht, 6/3/1943, Buchanan Files 8a/13.

31. Schultz, "Outline of a Presentation"; board member Thomas W. Keenan's letter to the editor, Des Moines Register, 9/9/1943.

32. Brownlee, "A Biography"; T. W. Schultz to George Godfrey, 6/16/1943, Buchanan Files 8a/2. See also H. H. Kildee to P. Mabel Nelson, 6/16/1943, Buchanan Files 8/11. 
Friley accepted Schultz's proposal, then decided to take the offensive in defining how social science should be done at ISC. He told the six faculty members of the Joint Committee that Pamphlet No. 5 "must stand or fall on its merits as determined by competent authorities on the basis of objective evidence." People dealing in the social sciences should, according to Friley, be able to reach unanimous conviction on the truth or falsity of the evidence. If any errors had been made in Pamphlet No. 5 with respect to such an absolute standard, ISC must own up to them. As he put it, "If we are wrong, we are in no way hurt by a free acknowledgment of the mistakes and prompt correction. If we are entirely right on any particular issue and are unanimous in that conviction, it is equally important that we stand for that right." The probing of Pamphlet No. 5 in light of such a standard was an urgent matter, one that "touches on the reputation of the College and of research men." 33

Brownlee quickly got a revised manuscript to Buchanan. It included a few new citations dealing with the qualities of margarine and smoothed some wording in general. Buchanan assured Friley that the Special Committee would complete a speedy review. He also informed Friley that another planned pamphlet, one by William Nicholls and John Vieg titled "Wartime Government in Operation," was ready for its final round of review. ${ }^{34}$

Friley reacted quickly to news about the latest pamphlet, deciding to scrutinize any policy analysis in it. The pamphlet's fifth round of revision had been accepted by the economics review committee, and Schultz now invited wider criticism for the final review. Buchanan decided to appoint a whole new interdepartmental review committee for that final critique. Within three days the five-person committee convened to report its findings. Friley showed up unannounced at the meeting and took Schultz and the committee chair aside, breaking the news that this new pamphlet simply could not be approved. Nevertheless, the meeting continued, with the committee approving publication by a 3-2 vote. The committee informed Buchanan of

33. Friley to H. H. Kildee et al., 6/16/1943, Schultz Files-Chicago 29/16.

34. Buchanan to George W. Godfrey et al., 6/23/1943, Buchanan Files 8/11; Buchanan to Friley, 6/22/1943, Buchanan Files 8a/3, Friley Files 6/9. 
the vote, and he requested one additional revision round to try for a unanimous favorable verdict. 35

By this time it was becoming clear that President Friley and Director Buchanan were trying to assert their own ideas about policy-oriented social science at ISC. Friley, as college president, needed to evaluate all campus activities in terms of their potential impact on the college, including its funding from the state as well as from donors. As for Buchanan, he had already shared with ISC's alumni that one of his main job responsibilities at ISC was to accommodate "many pressure groups, inasmuch as they have been responsible for past legislation creating and supporting the Iowa State College and in the future will be responsible for enactment of legislation relating to the institution." 36

What, then, would happen if the economic interests of Iowans who financially supported ISC came into conflict with ISC's contribution to the wartime interests of the nation as a whole? That was the unprecedented question at hand. One way for Friley and Buchanan to begin answering this challenging question was to deal with the Nicholls-Vieg manuscript.

Two days after learning of the 3-2 vote in favor of the manuscript, Buchanan informed Schultz that ISC needed to tighten its definition of allowable social science. "In my opinion," Buchanan explained, "it is not appropriate that the Agricultural Experiment Station use its funds for research in fields which have very little or no direct relationship to agriculture." It was not enough that the Nicholls-Vieg pamphlet might clarify arguments in an overall food policy being produced for wartime purposes; for even though the pamphlet might serve the "public good," Buchanan found no "reasonable justification" to believe that the pamphlet could meet the school's test of directly

35. William H. Nicholls, "A Narrative Chronology of Administrative Procedures Followed with Regard to a Manuscript, 'Wartime Government in Operation,' by William H. Nicholls and John A. Vieg," 1943, Schultz FilesChicago 29/16; E. W. Lindstrom et al. to R. E. Buchanan, 6/28/1943, Friley Files 6/9; Buchanan to E. W. Lindstrom et al., 6/30/1943, cited in Nicholls, "A Narrative Chronology"; Buchanan to Friley, 6/30/1943, Friley Files 6/9.

36. Charles E. Friley, "Iowa State College and the War Effort," Iowa Farm Economist, Feb. 1942, 2; Robert E. Buchanan, "What University Professors and Administrators Owe to Each Other," The Alumnus of Iowa State College, Nov. 1941, 67-69 (copy in Buchanan Files 5/4). 


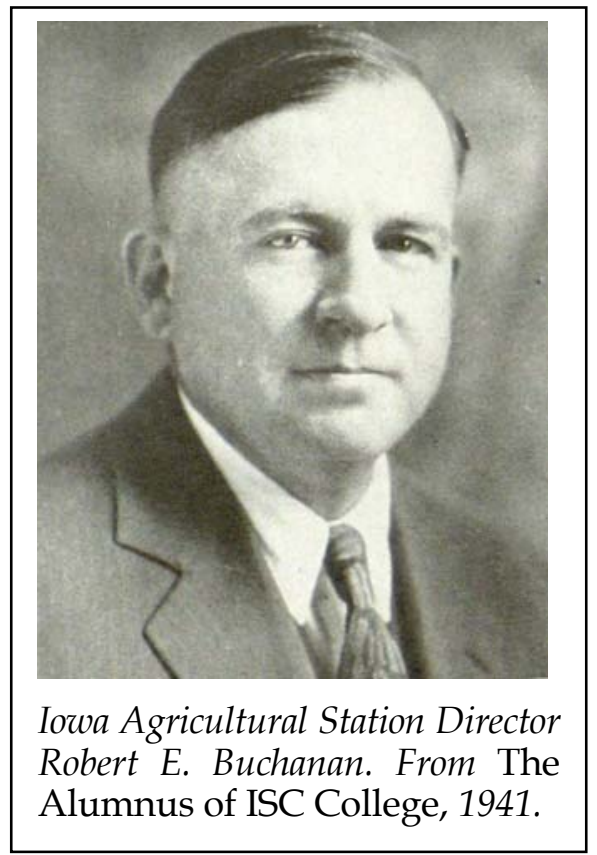

serving "as a benefit to agriculture." Furthermore, any social science to be done through the Agricultural Experiment Station must be as much like physical science as possible, in that it is "to be as objective as is possible and above all to avoid language which would indicate advocacy rather than objective analysis." 37

Buchanan noted that the 3-2 vote on the Nicholls-Vieg pamphlet was precisely split between representatives of the social and physical sciences, a division today's historians might describe as "two cultures" - the idea that "hard" scientists and "soft" scientists often hold some deep misunderstanding of each other's research methods. In keeping with Buchanan's and Friley's ideas that "truths" in social science need to be every bit as certain as truths in the physical sciences, Nicholls consented to one more manuscript revision in the pursuit of unanimous acceptance. Although attaining unanimity was a tall order, Nicholls recognized that Buchanan's role in redefining the pur-

37. Buchanan to Schultz, 6/30/1943, Friley Files 9/8. See also Buchanan to Carl Hamilton (assistant to the U.S. Secretary of Agriculture), 7/7/1943, Buchanan Files 8a/16. 
pose of social science was an "honest" effort "to establish a policy in a new area, under the severest of pressure." 38

But Friley now insisted that the Nicholls-Vieg pamphlet was absolutely unfit for publication by ISC, no matter what. "This is in no sense a policy-making institution," Friley declared, further hardening the reversal of his original support for the policy pamphlets: "We are on solid ground only as we study problems and present all facts which clearly arise from the research." Conclusions may be reached on the basis of facts, Friley allowed, "but we must distinguish very rigidly between our conclusions on the basis of fact and specific recommendation that one or another policy be adopted." Friley concluded that making policy recommendations "is entirely a governmental function." 39

Such an argument for a clean division between scientific and political functions in policy making was firm in academic discourse by the 1940s. The idea of social scientists as professional experts implied that society can simply provide social scientists with some preselected goal, and the social scientists will determine whether the goal is attainable and by what means. The political process can then place some values upon the situation by choosing between alternative means identified by detached and objective social science. ${ }^{40}$ Friley wanted particularly tight boundaries for the social scientists at his land-grant institution. The debate over the Nicholls-Vieg manuscript represented just one opportunity to impose his idea that complete agreement on all facts is attainable in social science.

38. Nicholls, "A Narrative Chronology." For the "two cultures" idea, see Charles P. Snow, Two Cultures and the Scientific Revolution (New York, 1960). Snow's argument-that a nearly intractable level of mistrust existed between persons in the hard sciences and those in the social sciences and humanities has been much debated. See D. Graham Burnett, "A View from the Bridge: The Two Cultures Debate, Its Legacy, and the History of Science," Daedalus 128 (1999), 193-218. After Charles M. Hardin visited ISC in the 1940s, he reported discovering deep "mutual distrust" in "a split between physical and biological scientists versus social scientists," and that split represented "one of the major obstacles to the fulfillment of publicly supported research institutions of their obligation freely and effectively to examine controversial issues." Charles M. Hardin, Freedom in Agricultural Education (Chicago, 1955), 122.

39. Charles E. Friley to R. E. Buchanan, 7/3/1943, Friley Files 6/9.

40. Michael A. Bernstein, A Perilous Progress: Economists and Public Purpose in Twentieth-Century America (Princeton, NJ, 2001), 15. 
AS FOR PAMPHLET NO. 5, Friley received the Special Committee's "final" report on June 30, and it was presented at a joint meeting of the Special Committee and Joint Committee on July 12. The report broadly criticized the pamphlet, but took no position on any disagreements concerning questions of comparable taste and nutritional value between butter and margarine. During the presentation of the report at the July 12 meeting, Clarence Nielson, reading the dairy group's prepared response, said that Pamphlet No. 5 was so full of "half truths" that it "should be condemned." Nielson accused Brownlee of avoiding citing even "a single nutritionist or dietician" from fear of seeing "his argument upset or his conclusions disturbed by the[ir] authoritative views." Brownlee had even violated the law, Nielson declared, by consistently referring to the product as "margarine" instead of "oleomargarine." Nielson demanded an explanation of how such a faulty work got published by ISC. Once Nielson was finished, the six faculty representatives conceded their agreement with the aggregate of the objections raised. ${ }^{41}$

All members of the Joint Committee recommended retraction. "It is unanimously agreed," they pronounced publicly, "that many of the statements contained in Pamphlet No. 5 are either incorrect or are susceptible to misinterpretation or are inadequately documented as to facts." Notice of that recommendation was communicated to Friley, who ordered the pamphlet rewritten and reissued. Friley soon sent an official retraction letter to all recipients of the original pamphlet. ${ }^{42}$

41. "Putting Dairying on a War Footing, an Analysis," 6/30/1943, Buchanan Files 8/5, Schultz Files-Chicago 29/18. Materials introduced at the meeting include: C. E. Friley, "Letter," 7/9/1943, Friley Files 2/27; T. W. Schultz, "Putting Dairying on a War Footing, Tentative and not for publication," July 1943, Schultz Files-Chicago 29/18; "Statement of Special Dairy Committee to President Charles E. Friley," July 1943, Buchanan Files 8/11, Friley Files 2/27.

42. "Report of the Joint Committee of Twelve Appointed to Review Pamphlet No. 5. July 12, 1943," Buchanan Files 8/11, Friley Files 6/10; Creamery Journal, Aug. 1943, 14, 22; Dairy Record, 7/28/1943, 12; Friley to Recipients of Pamphlet No. 5, 7/28/1943, Buchanan Files 8/11, Friley Files 2/27. Brownlee and Schultz considered the Special Committee's report as a turning point in Friley's attitude toward the social sciences. Brownlee thought that the report "definitely weakened Friley's stand" in defending policy research in the social sciences. Brownlee, "A Biography." Schultz identified the report as the point at which Friley concluded that he wanted to "shrink and limit the functions of 
How was unanimity achieved on the Joint Committee? Pressure to appease dairy interests was one clear factor. After receiving advice from such organizations as the National Dairy Council, the American Dairy Association, and the National Dairy Union, the Iowa Dairy Association "sharply disagree[d]" that the central issue in the controversy concerning Pamphlet No. 5 was one of academic freedom. Instead, it insisted that ISC was "accountable to the industry attacked, and to the citizens of the state": ISC was out of bounds in proposing policies potentially disadvantageous to basic industries in the state. 43

In addition, it appears that unanimity was considered the best face for ISC to put on for outside appearances. Schultz later explained his own vote by saying that the situation was a "most trying circumstance," and ISC needed to get moving ahead. "The faculty representatives were very anxious to patch up the matter, hoping somehow to reestablish working relations with the dairy interests. The dairy spokesman, however, came to the meeting instructed to settle for one thing and one thing only, namely the retraction of the pamphlet." 44

At a broader level, retraction seems to have been ISC's next move to harness the social sciences. Director Buchanan and Dean Kildee later shared their reasons for advocating retraction. Kildee, the non-voting Joint Committee chair, explained how inappropriate it would have been for a land-grant institution to allow its social scientists to recommend policy. It was nothing short of "amazing" to him "that this pamphlet was published by any unit of a land-grant college." Buchanan added, "The reason behind the action was that those involved in the state represent a large clientele with whom it is highly desirable that the College work amicably." ISC needed to "get faced in the same direction with the dairymen of the state in order to carry forward satisfactorily our programs of research and education." 45

social sciences so that controversial issues would be avoided." T. W. Schultz to Joseph H. Willits, 9/22/1943, Schultz Files-Chicago 29/23 (also in RAC-RF).

43. The words are from Fred Larrabee, president of the Iowa Dairy Association, in Creamery Journal, July 1943, 22, 27.

44. T. W. Schultz to Joseph Willits, 16 Oct. 1943, Schultz Files-Chicago 29/23.

45. H. H. Kildee to Carl Hamilton, 9/1/1943, Buchanan Files 8a/16; R. E. Buchanan to V. V. Malcom, 8/12/1943, Buchanan Files 8a/13. The President's 
Friley's retraction letter provoked many comments from its recipients. Leaders in agricultural economics were stunned. One of them, G. W. Forster, wrote to Schultz and asked, "Is this another case of interference with research by vested interests?" Schultz conceded, "We still have a long way to go in developing a procedure and organization in our land-grant colleges that will facilitate studies in the social sciences without fear or favor." Schultz viewed the situation of Pamphlet No. 5 as "a measure of . . . our willingness up to this point to tackle some of the really important and bigger issues in our economy." He feared that the progress of social science at public institutions had "probably been thrown for a substantial loss." 46

Edwin G. Nourse, formerly chair of ISC's Department of Agricultural Economics and now chair of the national Social Science Research Council, sent his comments directly to Friley. "When I received Pamphlet No. 5," Nourse explained, "I read it with deep interest and a feeling bordering on amazement. I thought that perhaps the time had arrived when a publicly-supported institution could present the results of objective study of economic problems with complete freedom, without pulling its punches or resorting to 'carefully contrived ambiguities' of statement." Friley's recantation alarmed Nourse, who believed that "the situation thus created is one of almost incalculable importance to every person interested professionally or merely as a citizen, in the preservation of opportunities for the conduct of objective scientific investigation and the uninhibited presenta-

Special Committee delivered its findings to Friley's office on July 14. The committee complained that all the data tables had yet to be checked and that some data seemed to come from "rather obscure sources." The committee also proclaimed that too much data was "in the comparative form which make them more obnoxious to many readers than if they were simple statements." "Report from Special Committee," 7/14/1943, Buchanan Files 8/11. No known comment exists from Friley on this Special Committee report.

46. G. W. Forster (professor of agricultural economics at the University of North Carolina) to T. W. Schultz, 8/9/1943; Schultz to Forster, 9/3/1943, Schultz Files 29/22. Schultz expressed similar views to another North Carolina agricultural economist and to Joseph Willits. Schultz to Sam H. Hobbs Jr., 9/2/1943, Schultz Files-Chicago 29/22; "Memo of phone conversation," Schultz with Willits, $8 / 11 / 1943$, RAC-RF. To Willits he suggested that the central issue in the controversy was the matter of how individual faculty members could publish policy arguments without a college needing to take the same policy position. 
tion of results." Friley replied that "the Iowa State College has always prided itself on the accuracy and high quality of its research work; it has tried to draw a clear distinction between research and advocacy." Pamphlet No. 5, said Friley, contained both faulty research and policy advocacy introduced "to a very great degree." 47

Nourse, in the meantime, contacted other leading agricultural economists to learn whether there really were any major factual errors in Brownlee's research. Karl Brandt of Stanford University's Food Research Institute responded, "I have not found in Mr. Brownlee's treatment of his subject any reason for such strong and startling exception to the statements made in the pamphlet as a majority of the members in the special adjudicating committee obviously have done." Brandt added, "How fortunate my colleagues and I are, indeed, in serving on a faculty of a privately owned institution." Brandt also wrote to Friley, reiterating his assessment that Brownlee had analyzed the dairy situation "without bias, and on the whole correctly." 48

The Iowa press extensively covered the retraction of Pamphlet No. 5. National farming magazines also reported on the controversy. Iowa citizens wrote letters to ISC, mostly accusing the school of capitulating to special interests. Even the national press took an interest in the controversy at a time when Americans had bigger worries on their minds. In the midst of war coverage, Time published an article titled "The Butter Atheist," and Newsweek facetiously reported that Iowa's dairy leaders had "found a traitor in their ranks" - the traitor being ISC. Even the Chicago Journal of Commerce expressed disbelief that President Friley and the ISC administration were trying to "bamboozle"

47. E. G. Nourse to C. E. Friley, 8/9/1943, RAC-RF; Friley to Nourse, 8/11/ 1943 , ibid. Another who wrote to Friley was ISC economist Walter W. Wilcox, who was then working in Washington. Wilcox reported that many people in Washington interpreted the retraction letter "as capitulation on the part of the Iowa State College to pressure group interests." Wilcox to Friley, 8/20/1943, Buchanan Files 8a/13, Schultz Files-Chicago 29/18. See also Buchanan to Wilcox, 8/23/1943, Buchanan Files 8a/13; Wilcox to Schultz, 8/27/1943, Schultz Files-Chicago 29/18; and Wilcox to Schultz, 9/7/1943, Schultz Files-Chicago 29/17.

48. E. G. Nourse to Karl Brandt, 8/10/1943, RAC-RF; Brandt to Nourse, 9/3/ 1943, ibid; Brandt to Friley, 9/3/1943, ibid. 
the public with "puerile actions" that have "cast suspicion on all future publications coming from faculty members" at ISC. As seen through the eyes of the nation's business leaders, the problem was clear: "If the pressure groups like the dairymen in Iowa get research conclusions revised merely by putting the squeeze on the college president and threatening to have the legislature cut the college's appropriations, why should anyone believe that any of the college's future research publications are impartial and not written with an eye to catering to the prejudices of the producers around the state?" 49

Under such pressure, Friley and Buchanan moved to get the revision process under way. On July 27 they agreed to reappoint the President's "Special Committee" to oversee the process. ${ }^{50}$ Friley also directly contacted the Iowa State College Press to demand reorganization of the press's editorial board. By the end of July, Friley had successfully removed the economics review committee from any oversight of the pamphlets and reassigned all review powers over the pamphlet series to the press's reorganized editorial board. Friley even personally removed a professor of journalism from chairing the editorial board, substituting a professor of animal husbandry. For added measure, Friley removed the lone social scientist (Margaret Reid) from the editorial board. As a result of these changes, Friley "anticipated" no foreseeable reason why the College Press's new editorial board "will at any time delegate its authority for review of manuscripts to any other committee or organization." 51

49. In addition to more letters to newspapers, numerous letters to ISC are in the Buchanan Files, Friley Files, and Schultz Files-Chicago. See also Harry O'Brien, "Less Butter, More Bread," Country Gentleman, Aug. 1943, 18, 27; W. A. Gordon, "The Farmer Rebels with Printer's Ink," Successful Farming, Aug. 1943, 11; “The Butter Atheist," Time, 8/2/1943, 86; "Iowa and Margarine," Newsweek, 6/14/1943, 72, 74; "Research at Iowa State College," Chicago Journal of Commerce, 7/31/1943, 12 (copies in Buchanan Files 8/13 and 8a/1). The Chicago Journal of Commerce editorial upset Buchanan and others at ISC. Buchanan shared his view in R. E. Buchanan to V. V. Malcolm, 8/12/1943, Buchanan Files 8a/13. Leroy D. Snyder, president of the Iowa State College Alumni Association, responded to the editorial in "ISC Criticism Challenged," The Alumnus of Iowa State College, July-Aug. 1943, 3.

50. R. E. Buchanan to Special Committee, 7/27/1943, Buchanan Files 8/11.

51. Friley to Buchanan, 6/1/1943, Friley Files 9/8; Buchanan to Friley, 6/8/1943, ibid.; Buchanan to Friley, 6/22/1943, Buchanan Files 8a/3. For more about the 
The situation at ISC took a new turn for the worse when the ISC administration used the Nicholls-Vieg manuscript to further redefine the nature of allowable social science. Roger Fleming, director of research at the Iowa Farm Bureau, submitted comments on the manuscript, suggesting that if social scientists at ISC were to advocate policy in any way, they should seek "to present an accurate, understanding and sympathetic orientation of the broad discussion to the Iowa situation." Leland G. Allbaugh, associate director of the Extension Service, agreed that ISC's social scientists should serve Iowa's interests first. Subsequently, even though the interdepartmental review committee's mix of physical and social scientists unanimously approved the pamphlet's sixth revision, President Friley overruled the committee and rejected the manuscript for publication by ISC. Nicholls, deciding that further pursuit of the principle of the matter was not worth his energy, got the pamphlet published elsewhere, with support from the American Council on Public Affairs. Reflecting on the whole matter once it was over, Nicholls wrote that he "felt like a person put on trial for a murder he did not commit who, after five appeals, was relieved to get the death sentence." 52

TWO MONTHS LATER, the entire controversy reached a head, when Schultz unexpectedly resigned from ISC. The final straw, it seems, had been Friley's newest approach to finding a solution. On August 16 Friley had moved to appoint yet another four-person committee. This "Committee to Reorganize the Department of Economics and Sociology," headed by Extension Service director R. K. Bliss, was assigned the weighty responsibility "to make a thorough study of the organization, functions, program and relationships" of the department, yet it

reorganization of Iowa State College Press's editorial board in 1943, see Russell Paul Kaniuka, "A History of the Iowa State University Press" (M.S. thesis, Iowa State University, 1961), 34-35.

52. Nicholls, "A Narrative Chronology." The Nicholls-Vieg pamphlet was published as William H. Nicholls and John Vieg, Wartime Government in Operation (Philadelphia, 1944). It was dedicated to T. W. Schultz for "his devotion to unbiased scholarship and the general welfare." Friley is nowhere in the book's substantial list of kindly acknowledged colleagues, but Nicholls added a handwritten statement to the copy in the Iowa State University Special Collections: "To President Friley with the best personal regards of William H. Nicholls." 
included no one from the department, and was even ordered not to communicate with anyone from the department. The new committee's work was well under way by mid-September. 53

Schultz's resignation letter, dated September 15, emphasized his displeasure over the handling of Pamphlet No. 5, dealings with the Nicholls-Vieg manuscript, the removal of the lone social scientist from the press's editorial board, and a host of related matters. Schultz held President Friley responsible for the "crisis in the development of the social sciences on this campus." Although in the past ISC had encouraged "an unusually vigorous development" of the social sciences, Friley had compromised ISC's public purpose by cowering to special interests, causing "a serious loss of confidence in the integrity of the Iowa State College both on the part of its faculty members and on the part of scholars elsewhere." Schultz emphasized ISC's error: "The failure to have served, first and foremost, the general welfare of the state and nation has quite understandably created expectations that the facilities and faculty of Iowa State College were primarily here to serve agriculture in ways prescribed by the organized pressure groups in agriculture regardless of the effects of what was done upon the public interest generally." Schultz urged Friley to inform the faculty in the social sciences that "there is to be freedom to work on national and other problems, even though they are controversial in nature." 54

Schultz and Friley met personally two days after Schultz resigned. Immediately thereafter, Friley held a news conference to announce the resignation, which was covered by Iowa's newspapers. The press also published excerpts from Schultz's letter, thereby introducing Iowans to Schultz's argument that Iowa pressure groups endangered free inquiry in the social sciences. ${ }^{55}$

53. C. E. Friley to R. K. Bliss et al., 8/16/1943, Friley Files 6/15.

54. "Form S-3, Iowa State College, Resignation," T. W. Schultz, 9/15/1943, Schultz Files-Chicago 29/17; Schultz to Friley, 9/15/1943, Buchanan Files 8/7, ibid., 29/16. Schultz's letter also urged Friley to discontinue the pamphlet series; cease any further administration of Rockefeller Foundation funds without Schultz's approval; and disband the committee recently established to limit the functions of the Department of Economics and Sociology.

55. "Schultz Resigns as Economics Head at State College," 9/17/1943, Information Service, Iowa State College, Ames, Buchanan Files 8/14; Des Moines Register, 9/18/1943, 9/19/1943. The Cedar Rapids Gazette, 9/19/1943, pub- 


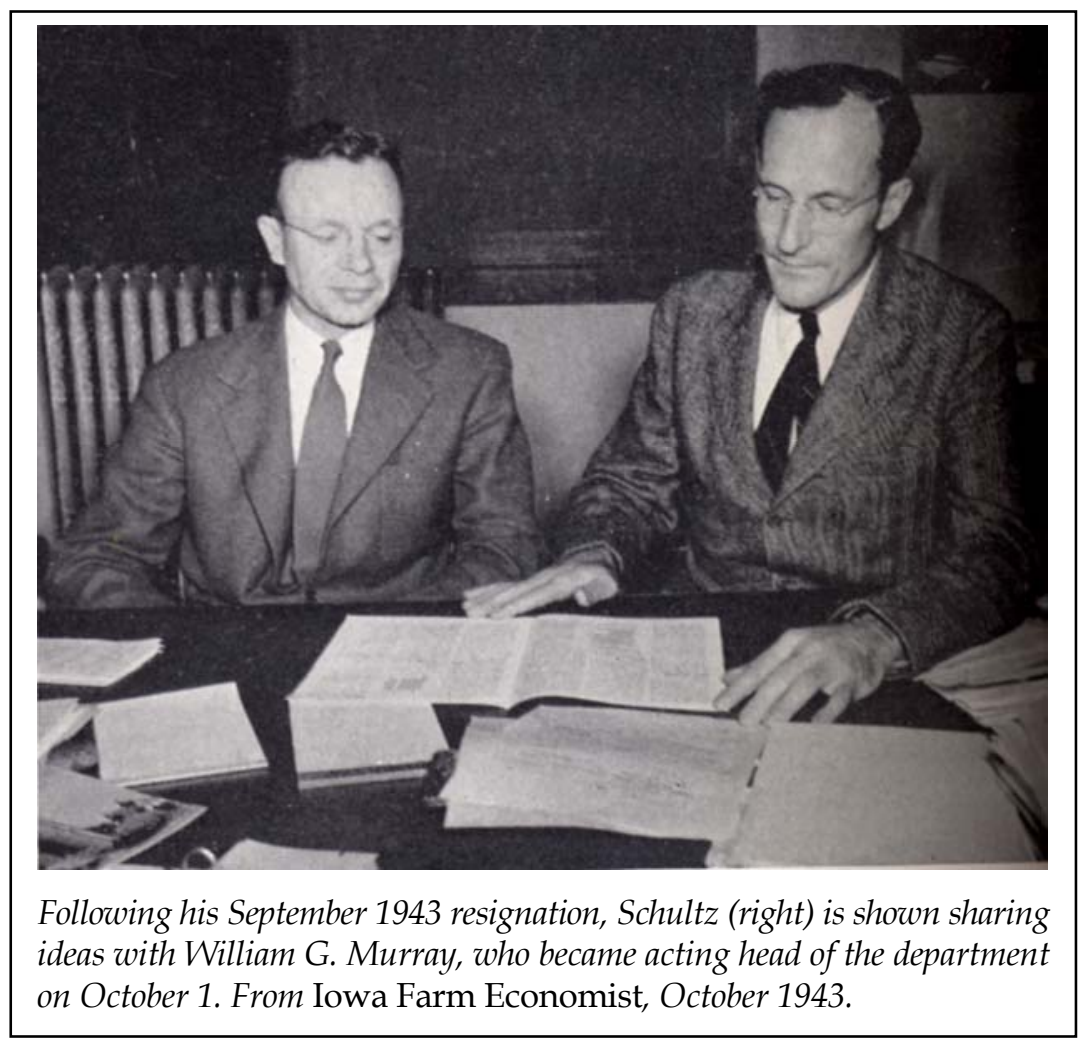

Governor Bourke B. Hickenlooper immediately stepped forward to express confidence in Friley and the ISC administration. Francis Johnson, president of the Iowa Farm Bureau Federation, also rallied to support Friley, describing the situation as a "minor incident," merely a corrective in the "fight to keep Iowa State College an institution of "practical agricultural education and scientific research along agricultural lines.' " 56

lished lengthy excerpts from Schultz's letter and independently confirmed the likelihood of a series of resignations from the economics faculty. See also Dairy Record, 9/22/1943, 8, 25.

56. Cedar Rapids Gazette, 9/20/1943, 9/22/1943. On the other hand, Donald W. Van Fleet, president of the Iowa Farmers Union (and an opponent of Francis Johnson's strategies against ISC economists), began a letter-writing campaign to the governor requesting outside investigation of Friley and ISC. See five letters (from 9/22/1943 to 10/14/1943) between Van Fleet and Governor Hickenlooper in Friley Files 6/12. 
Wallaces' Farmer, on the other hand, recognized Schultz's resignation as a "great loss" for ISC as well as "in the larger field of public affairs." The central issue in the Pamphlet No. 5 controversy, as Wallaces' Farmer interpreted it, was what kind of social science would be allowed at ISC. To be useful, economists "must deal with pressing and controversial issues." ISC's economists are expected to be as impartial as possible, and to present facts as they see them. "But so long as it bases its conclusions on the best evidence it can find, nobody should object, altho some may squirm and altho others may-quite properly -ask for further investigation into the facts." The editorial added, "You can't cure cancer by telling the doctor you don't believe in it, and that he is to find another diagnosis. So, in economic diseases, we need to let the economists do the best they can without any orders as to what the diagnosis should be." 57

Schultz finished his days at ISC writing letters to friends. To one he acknowledged that an open job offer from the University of Chicago "has given me an opportunity to do what needed to be done here." A once "favorable environment" for the social sciences, Schultz wrote, had turned sour due to a notion that the ISC economists' policy studies "were not in harmony with the program and policies advocated by the National Farm Bureau Federation." Schultz expressed deep concern that the nation may be losing a research center "of great promise"; yet he maintained hope "that the tolerance, concern, and good judgment of the many leaders in this state will bring with them the necessary 'light' to help cure the wounds." "We have not as yet developed the necessary safeguards for social science studies in a land-grant college such as this." What was urgently needed was to establish "institutional arrangements which will protect the Iowa State College and other land-grant colleges when they undertake vital and courageous research in the social sciences." 58

57. Wallaces' Farmer and Iowa's Homestead, 10/2/1943, 6.

58. Schultz to James G. Patton (president of the National Farmers Union), 9/23/1943, Schultz Files-Chicago 29/23; Schultz to Joseph H. Willits, 9/22/ 1943, ibid. See also Schultz and Willits, phone conversation, 10/11/1943; Willits to Schultz, 10/11/1943, RAC-RF; Schultz to Willits, 10/16/1943, ibid. Other letters Schultz wrote during his last days at ISC include ones to Jim Russell (farm editor, Des Moines Register), 9/19/1943, Schultz Files-Chicago 29/23; Donald Murphy (agricultural editor, Des Moines Register), 9/28/ 1943, ibid.; 
In an open letter titled "Iowa State College and Social Science Research," Schultz explored the relationship between ISC and special interests and discussed why policy research was needed at ISC. Successful resolution to the broad controversy, he explained, might ultimately depend upon whether "the people of Iowa believe, as I think they do, that the most serious problems affecting their well-being over the next few decades lie in the fields of economics, government and social organization." If Iowans take that view, then they will want social research that is "consistent with the general welfare of society." Iowans must ask: "Should state supported institutions such as Iowa State College assume a far greater part of the necessary research and educational functions of the social sciences?" Schultz hoped readers would decide that "unbiased research in the social sciences can be prosecuted with vigor" at ISC. 59

Friley moved to control the damage. Despite the evidence to the contrary, he was convinced that the "range of comments both on and off the campus unanimously condemns the manner in which [Schultz] had handled the situation." 60 To set matters right, he called a meeting with the economics faculty. Before the meeting, the faculty submitted a memo expressing their main points of discontent, consolidating their most pressing concerns under the banner, "Controversial Issues and the Social Sciences." They called for dialogue to explore the balance between faculty research for short-run goals of special interests and faculty research for the public interest. Above all, they wrote, ISC must "recapture and preserve the respect and confidence that has existed in the past throughout the state and the nation." 61

and Charles H. Brown (head librarian, ISC), 9/28/1943, Schultz Files-Chicago 29/16. Schultz also received many letters from friends in the days following his resignation. See Schultz Files-Chicago 29/23. One who wrote was Edwin G. Nourse, who said that ISC's tendency to suppress free expression of ideas dated back to an earlier "troubled period" of free expression at ISC during the 1910s and 1920s. E. G. Nourse to Schultz, 10/4/1943, RAC-RF.

59. Des Moines Register, 9/24/1943.

60. C. E. Friley to Richard H. Plock, 9/23/1943, Friley Files, 6/12.

61. "Memorandum to the President's Office from the Faculty of the Department of Economics and Sociology," 9/22/1943, Schultz Files-Chicago 29/23. The memorandum was signed by economists Arthur Bunce, D. Gale Johnson, Frank Robotka, Geoffrey Shepherd, and Wallace Wright. 
Friley, however, was set on going his own way. After meeting with the economists, he released his "Statement of Policy" concerning the limits to be placed on social science at ISC. "The staff of the Iowa State College," Friley stated in no uncertain terms, "must work in full and sympathetic cooperation with all agencies in the State which are working for the welfare of the State as a whole, or any of its segments." ISC's social scientists were, in other words, to be "servants of power." 62

By the end of September, the American Association of University Professors (AAUP) was aware of the controversy and announced a "probable" investigation of "suppression of 'academic freedom" " at ISC. The AAUP was especially interested in investigating "larger issues concerning the relation of publicly controlled education institutions to private interests and the public at large." Friley responded to the possible outside investigation by sending Buchanan to Washington to assure the AAUP that ISC would publish some version of a revised Pamphlet No. 5. Evidently Buchanan provided enough information to keep the AAUP at bay. ${ }^{63}$

But newspapers in the state were again picking up the question of what kind of social science was to be allowed at ISC. An October commentary in the Ames Daily Tribune, for example, suggested that the central issue that "must be taken into account... is that the social sciences are not precise sciences. On many questions it is possible for another person in the field to take a different-even an opposite-position from Doctor Schultz and still be considered as competent an economist as he." The Des Moines Register, that same month, featured Schultz supporter Thomas W. Keenan offering historical comparison:

When Copernicus reported his conclusion that the sun did not revolve around the earth but that the earth revolved around the sun, there was plenty of 'studied judgment by qualified authorities' to

62. "Friley Repledges College to Service to State of Iowa," Information Service, Iowa State College, Ames, Friley Files 2/27. The term servants of power comes from Loren Baritz, The Servants of Power: A History of the Use of Social Science in American Industry (Middletown, CT, 1960).

63. Des Moines Register, 10/2/1943; President Charles E. Friley to Ralph E. Himstead, 10/5/1943, Buchanan Files 8a/15. See also Himstead to Friley, 4/12/1944, Buchanan Files $8 \mathrm{a} / 15$. Copies of correspondence between AAUP representatives and ISC faculty and administrators are in the AAUP Archives, Washington, DC. 
the effect that he was a heretic. If he had been on the faculty at I.S.C. would the college have refused to assist in publicizing that report? When Harvey reported that the blood in our bodies circulated through the veins and arteries there was plenty of 'studied judgment by qualified authorities' to the effect that he was crazy; so we would have turned thumbs down on him and he would have gone to the University of Chicago. ${ }^{64}$

STILL UNRESOLVED through all this was the matter of revising Pamphlet No. 5. By mid-October, Friley's reappointed Special Committee approved Brownlee's outline, which was substantially the same as for the original pamphlet. ${ }^{65}$

By the end of the month, however, Buchanan set another ball in motion, this one aimed at producing an "official" statement of what could be allowed from social science in relation to the mission of a public, land-grant institution. Buchanan established yet another committee, named the "Committee on Sponsorship of Publications." Buchanan informed the committee's five members (including two social science representatives) that he had been "unable to find any adequate discussion of this problem in the writings relating to the land-grant colleges and experiment stations." He directed the new committee to scrutinize every applicable congressional act and then formulate written rules. 66

The situation for Pamphlet No. 5 became even more unclear when, between mid-November and mid-December, two members of the Special Committee resigned. Friley handpicked a respected professor of chemistry, Ralph M. Hixon, as the new committee chair. ${ }^{67}$ Hixon promptly declared that the Special

64. Ames Daily Tribune, 10/1/1943 (emphasis in original); Des Moines Register, 10/24/1943.

65. Oswald Brownlee to T. W. Schultz, 10/12/1943, Schultz Files-Chicago 29/21. 66. R. E. Buchanan to Members of the Committee on Sponsorship of Publication, 10/25/1943, Buchanan Files 10/17.

67. B. W. Hammer resigned on November 23, providing no reason; committee chairman George Godfrey resigned on December 14, citing ill health (he died two months later). Iver J. Johnson, already chairman of Buchanan's new "Committee on Sponsorship of Publications," replaced Hammer. Another new committee member, C. A. Iverson, was also added. Buchanan to R. M. Hixon, 11/23/1943, Buchanan Files 8/11; George Godfrey to Buchanan, 12/14/1943, ibid.; Buchanan to Ray Anderson, 2/25/1944, Buchanan Files 8/13. 
Committee would take over the rewriting of Pamphlet No. 5. Margaret Reid, on leave in Washington, expressed alarm over the precedent such an action would establish. Reporting that leaders in Washington were counting on him, she encouraged Brownlee "not to let your impatience to get finished lead you to consent to anything to which you do not fully subscribe." Reid wrote to Buchanan the same day, suggesting that the members of the Special Committee "have been asked to appraise something outside the special field of competence of every one of the members." She added that "suspicion deepens in many quarters that no publication will be forthcoming." 68

ISC was, in fact, getting flogged on the national stage. In October Time published a report that an ISC graduate student had produced a "disinterested oleopus," but the Iowa Farm Bureau had declared it foul. Such a pamphlet "might befit scholarly Harvard," the article reported the Farm Bureau crying, "but was disloyal in a cow college." According to the traditionally conservative Reader's Digest, Brownlee had published an informative and balanced collection of facts only to discover that "there was the very devil to pay." Dairy interests "demanded Brownlee's scalp"; Schultz then "chucked his job and escaped to Chicago," while President Friley "placated the dairy interests by disowning the heretical tract." Harper's Magazine reported that margarine, suddenly charged with "the power of dynamite," had ignited an explosion that has "blown up the works at Iowa State College of Agriculture-through the suppression of a pamphlet enumerating the virtues of margarine during the wartime butter shortage." 69

68. Margaret G. Reid to O. H. Brownlee, 12/23/1943, Buchanan Files 8a/1; Margaret G. Reid to R. E. Buchanan, 12/23/1943, Buchanan Files 8a/2.

69. "Cowed?" Time, 10/11/1943, 40; Harland Manchester, "Here's Why There's Nothing to Spread on Your Bread," Reader's Digest, Dec. 1943, 49-52; Wesley McCune, "The Oleomargarine Rebellion," Harper's Magazine, Dec. 1943, 10-15. The National Union Farmer (Denver, CO) sided with academic freedom against the arguments of the Farm Bureau. Complicity between the Iowa Farm Bureau and ISC, the magazine reported, "has forced the resignation of a nationally known professor . . . because he would not compromise academic standards and freedom at the demand of the Extension Service's pressure group." "Professors May Probe Extension," National Union Farmer, 10/15/1943, 1. See also Boston Herald, 11/15/1943. 
President Friley reacted by assuring Iowa taxpayers and ISC donors that all future college publications would be tightly controlled and would be required to pass through strict procedures of "faculty review, criticism and final approval provided by institutional regulations." Buchanan, for his part, remained optimistic that the new Committee on Sponsorship of Publications would soon clarify "this whole problem of sponsorship [of ISC research] and its possible relationship to academic freedom." As for Pamphlet No. 5, Buchanan emphasized that he wanted to see a revision published as much as anyone, but that the entire matter was not up to him, or even to Friley. "For me to step in and issue a directive," he commented, "I am quite sure would do more harm than good." And, he continued, no matter what the Special Committee decides, nothing would be published unless the original author, Brownlee, agreed to it. Friley and Buchanan considered the matter settled, that is unless Brownlee or Reid decided to risk initiating any objection. Neither of them did. 70

When Hixon learned that Brownlee had "accused" his Special Committee of "attempting to rewrite the pamphlet," however, he told Brownlee that he should see the offer of rewriting services as providing "a means of assisting" him. Hixon added that the committee now had major problems with Brownlee's previously approved revision outline. ${ }^{71}$

Within two weeks, Brownlee responded to the committee's edited materials and request for revision, enclosing his latest revision and calmly explaining that he had attended to all points of criticism, agreeing on some but disagreeing on others.

70. Charles E. Friley, "Right to Speak or Publish-Has Never Been in Question," Alumnus of Iowa State College, Dec. 1943, 75; R. E. Buchanan to Margaret Reid, 12/27/1943, Buchanan Files 8a/1. Leroy D. Snyder, president of the ISC Alumni Association, also reassured ISC's supporters. Admitting that the ISC community had been "stunned by the nationwide comment," he explained that the retraction was best interpreted as "a mark of courage, an evidence of integrity" when a review board "finds questionable conclusions." L. D. Snyder, "Answers Criticism at ISC," Iowa State College Bulletin-News of ISC, 10/13/ 1943. Buchanan, for his part, assured Snyder that he did "not believe there is any significant question of academic freedom now before us." Buchanan to Snyder, 12/16/1943, Buchanan Files 8a/13.

71. R. M. Hixon to Brownlee, 1/5/1944, Buchanan Files 8a/2. Hixon now described the pamphlet as "excessively documented." Hixon to Buchanan, 1/6/ 1944, Buchanan Files 8/11. 


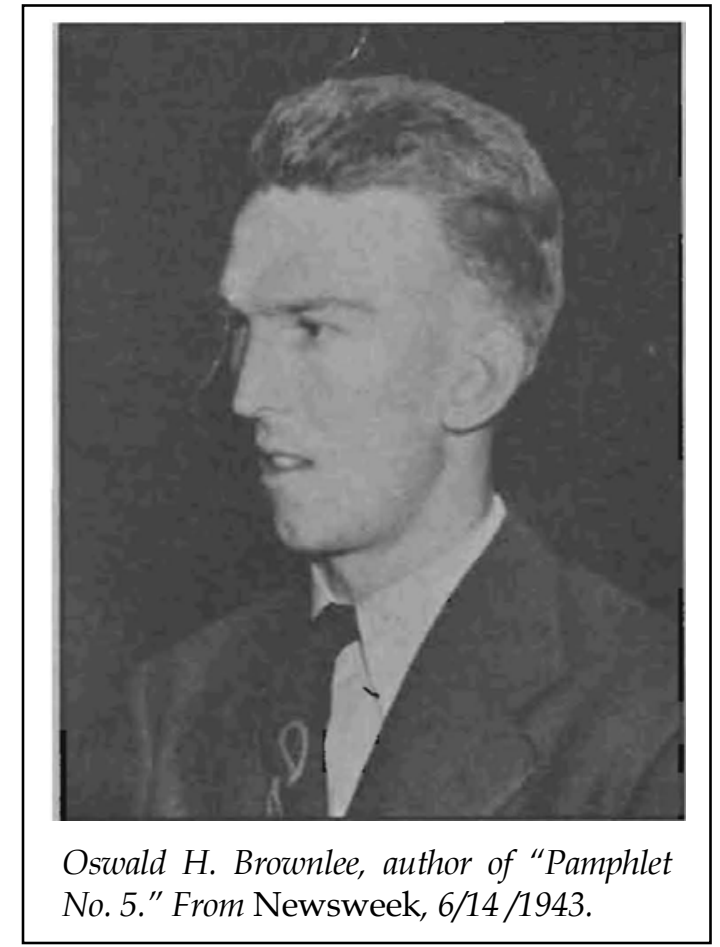

As requested, Brownlee placed increased emphasis on the nutritive value of dairy products, but maintained that margarine needed to be noted as an available substitute for butter. Margarine, Brownlee insisted, "has to be mentioned rather freely in the reissue." The "emphasis given to various points," he conceded, "is a matter of judgment." If the Special Committee still disagreed with anything, "I would suggest that you be given space running concurrently with my presentation for rebuttal." 72

Hixon had failed to provoke Brownlee into expressing anything regrettable. Still, the Special Committee found the latest revision unacceptable. Writing to Buchanan on January 28, the committee described Brownlee's writing as "argumentative and misleading," and found that all of his revisions "lack objectivity." The committee added that Brownlee has turned "so dogmatic in his convictions that he is unable to see the problem in its proper

72. Brownlee to Hixon et al., 1/21/1944, Buchanan Files 8/11. 
perspective." The committee, presumably seeing the proper perspective, now wanted the "dominant theme" to be the analysis of problems associated with shifting milk production away from using milk products for animal feed (especially for calves and hogs) to producing more milk products fit for human consumption. At the same time, the committee recommended dropping all discussion of oleomargarine, which perhaps might be included in some future college pamphlet focusing on comparison of different fats and oils. Hixon further recommended that Buchanan take the time to recruit two more new committees, one to be made up of Experiment Station personnel who would receive any future revisions, a second that would be some kind of all-college group responsible for rewriting the pamphlet as they might see fit. Hixon ended his insubordinate letter by declaring that the Special Committee's work was done. ${ }^{73}$

Buchanan was incensed. He ordered Hixon and the Special Committee to meet with the economics faculty to share their latest findings, and he praised Brownlee for showing great patience through the entire process. If ever there had been a hint of misunderstanding, "the author has taken it upon himself to clear matters promptly and has volunteered to my office all correspondence that had pertinence." Fully aware that Hixon's Special Committee wanted to avoid any further responsibilities, Buchanan reminded the committee that republication was not to be partially deferred to a future pamphlet on fats and oils, but was to be in one pamphlet-as ISC had announced publicly. Republication was both "necessary" and "overdue." Buchanan thanked the committee for their service, but, he added, it was certainly not dismissed. ${ }^{74}$

Buchanan did, however, add one new committee: a focused review group that would need to work fast. Supposedly a subcommittee of Hixon's Special Committee, this four-person group, including Brownlee and Buchanan, would work out its own conclusions on Pamphlet No. 5 and then submit them to

73. Hixon et al. to Buchanan, 1/28/1944, Buchanan Files 8/11.

74. R. E. Buchanan, "A Statement to the Joint Meeting of the Committee on Review of the Manuscript of Pamphlet No. 5 and the Advisory Council of the Department of Economics and Sociology," 1/28/1944, Buchanan Files 8/11, Friley Files 2/27. 
Hixon's committee. If, in the end, any person on Hixon's committee still disagreed on pamphlet content, "consideration will be given to inclusion of his signed objections in an appendix." The new review group met every day for two to four hours through the last week of January and well into February. ${ }^{75}$

By the end of January, Buchanan's Committee on Sponsorship of Publications came through with a draft of its new social science regulations. The draft was distributed to readers, and feedback returned to Buchanan during the following weeks. One respondent was Schultz, now at the University of Chicago. Schultz respected the effort in general, but expressed a "feeling of uneasiness" that any restrictive guideline on social science would likely lead the college to "screen out" quality scholarship, causing certain kinds of critical opinion to "tend to go underground." Researchers in the social sciences might even turn so "discreet" that they would not put themselves on record. ${ }^{76}$

The Committee on Sponsorship of Publications submitted its finished report in early February, and Buchanan released a 13-page statement of policy for all social science at ISC. The statement cited wording newly discovered in the 1935 Bankhead-Jones Act to the effect that the U.S. Secretary of Agriculture, as the ultimate overseer of the nation's system of experiment stations, is "authorized and directed to conduct research" to identify "new and extended uses of and markets for agricultural commodities and by-products and manufactures thereof." Such wording-specifically the search for "extended uses of and markets for" - perhaps was instrumental in the new recommendation to allow policy research by social scientists so long as "publication directly by the author does not in any way predicate experiment station sponsorship for the ideas, opinions or conclusions expressed." The report added, "There is no reason

75. Buchanan, "A Statement to the Joint Meeting." One member from Hixon's committee (B. H. Thomas) would be on the new subcommittee as would one faculty member from the economics department (D. Gale Johnson). Buchanan served as chair.

76. "Sponsorship of Publications by the Agricultural Experiment Station," draft manuscript, January 1943, Buchanan Files 10/17; Schultz to Buchanan, 2/4/1944, ibid. John A. Vieg also commented on the draft report, sharing Schultz's concerns. Vieg to Buchanan, 2/22/1944, Buchanan Files 8a/13. 
for committees or other formal proceedings before publication." In conclusion, "the desirable way to handle such publication is really that of scientific papers in general," that is, "informal [peer] review by colleagues in the experiment station itself or, still better, in the wider field of international science." 77 The final report of the Committee on Sponsorship of Publications did not say what to do about Pamphlet No. 5.

Hixon's attempt to stop the revision process suggested to some observers the need for increased pressure by outside interests capable of challenging Iowa special interests. On February 10 John Vieg, then on leave in Washington, wrote to inform Friley that the AAUP was preparing to send an investigating committee to Ames. Vieg had spoken to AAUP secretary Ralph Himstead to try to persuade him to hold off sending a committee a little longer. In light of this favor he was doing for Friley and ISC, Vieg strongly urged Friley to get a revised Pamphlet No. 5 published "without much additional delay." 78

On February 12, the Des Moines Register reported that a "reliable source" said the revised manuscript had gotten only as far as Buchanan's desk, and that Buchanan's actions must be the holdup. Yet Buchanan was also quoted directing blame at Hixon's committee: "I had hoped it would be out before this. The committee just hasn't done the job." Buchanan disclaimed the quotation, calling it a "fabrication." He explained to Hixon that he had never assigned such blame to Hixon's committee. Yet Buchanan admitted that "a series of mistakes [were] made ... in handling the problem of the famous Pamphlet No. 5." 79 He only

77. "Sponsorship of Publications by the Agricultural Experiment Station"; Report of a Special Committee Appointed by the Director," R. E. Buchanan to Members of the Agricultural Experiment Station Staff, 2/11/1944, Buchanan Files 10/17, esp. pp. 3-4.

78. John A. Vieg to Charles E. Friley, 2/10/1944, Friley Files 6/14. The Ames Tribune, $1 / 21 / 1944$, reported that the AAUP was considering whether to investigate partly because of a request by Donald Van Fleet, who had placed such a request after the State Board of Education and Governor Hickenlooper had each declined to make any investigation. The State Board of Education had said simply, "The charge of the violation of the fundamentals of academic freedom in all particulars is without foundation in fact." See also Henry C. Shull to Governor B. B. Hickenlooper, 11/5/1943, Friley Files 2/27.

79. Des Moines Register, 2/12/1944; Buchanan to Members of the Review Committee on "Pamphlet No. 5," 2/14/1944, Buchanan Files 8/11; Buchanan to J. S. 
hoped that those mistakes would not result in the "complete disintegration" of a fine economics department, a situation that appeared increasingly likely. 80

Meanwhile, an exasperated Vieg in Washington notified Buchanan that he would no longer try to postpone any impending investigation by the AAUP. Friley had written to Vieg, stating, "I have just learned that the final copy is being typed today, and I hope it can go to press very shortly." Perhaps Friley hoped that Vieg would dutifully pass such information to the AAUP. Vieg did not believe him, however. In fact, Friley's claim was false, and he knew it. Buchanan had recently informed Friley that the situation was entirely different from what Friley reported to Vieg, and certainly did not claim that the pamphlet was imminently forthcoming. Buchanan responded to Vieg, emphasizing the importance of letting the newly structured review process run its course. Buchanan was tired of so much "undue pressure from various friends." In an odd way, he might welcome an outside investigation; at least a group such as the AAUP might stand a chance of running a review process that is "properly conducted." 81

Russell (farm editor, Des Moines Register), 2/14/1944, Buchanan Files 8a/10; Russell to Buchanan, 2/15/1944, ibid.; Buchanan to Russell, 2/17/1944, ibid. The person who had said that the revised manuscript languished in $\mathrm{Bu}$ chanan's hands was Russell's own daughter, a journalist for the Register (and, indeed, a "reliable person"). In his February 15 letter, Russell demanded to know the truth, noting that the status of the revision is "the public's business." Buchanan provided a detailed response on February 17. The specific mistakes Buchanan now recognized were (1) that a pamphlet intended as an "unsponsored publication" did not come across that way; (2) that ISC had failed to notice that the Iowa Farm Bureau (in particular Francis Johnson) had certain objectives stemming from other grievances; (3) that the faculty members on the original Joint Committee conceded too much on certain points raised by the dairy representatives; and (4) that the President's Special Committee included no one from the Economics Department.

80. Indeed, by this time the report out of Ames was that many economists had resigned or were on the verge of doing so. In addition to the resignations of Schultz and Walter Wilcox (who was also a member of the original economics review committee), it now appeared that at least four other economists were planning their exodus. Des Moines Register, 3/3/1944.

81. Vieg to Buchanan, 2/22/1944, Buchanan Files 8a/13; Friley to Vieg, 2/16/ 1944, Friley Files 6/14; Buchanan to Friley, 2/7/1944, Friley Files 9/8; Buchanan to Friley, 2/17/1944, ibid. Buchanan to Vieg, 2/28/1944, Buchanan Files $8 \mathrm{a} / 17$. Buchanan corresponded as well with Walter Wilcox, now at the Uni- 
The AAUP informed President Friley on April 12 that their investigation was serious. Himstead explained that the AAUP ultimately wanted to investigate "the relationship of Iowa State College to the public." Friley, responding on May 2, asserted that Himstead's view was based on "wholly untenable hypotheses" which "might well lead to a questioning of the objectivity of your inquiry." 82

The American Civil Liberties Union (ACLU) was also threatening an investigation. In an article in The New Republic, J. M. O'Neill, who chaired the ACLU's Committee on Academic Freedom, identified the case at ISC as concerning "the freedom to speak, to teach, to publish the truth as he sees it on the part of the teacher and research scholar." President Friley, O'Neill charged, had "given up without a fight the fortress for truth and the public interest." 83

ISC economist Albert G. Hart was the first to respond to $\mathrm{O}^{\prime}$ Neill. Hart corrected minor misunderstandings of certain details and asked O'Neill to clarify whether the ACLU planned to investigate. Buchanan wrote next, agreeing with O'Neill's overall opinion of the importance of academic freedom, but he could "conceive of nothing in this procedure which in any way involves academic freedom." Furthermore, he was astonished that O'Neill had made so many incorrect statements about a situation that was much more involved than $\mathrm{O}^{\prime} \mathrm{Neill}$ recognized. Bu-

versity of Wisconsin. Wilcox believed that Hixon's committee would never approve a revision, and he suggested that such a conflict would never happen at Wisconsin. To that Buchanan responded: "What has the University of Wisconsin ever done to seriously combat the domination of the dairy pressure groups in that state?" Wilcox to Buchanan, 2/14/1944, Buchanan Files 8a/15; Buchanan to Wilcox, 2/17/1944, ibid. Wisconsin actually was little different from Iowa on the issue at hand. The New York Times, 11/7/1943, reported that Wilcox had first had to be cleared of any close association with Pamphlet No. 5 before the State Board of Regents would approve his appointment. See also May 1944 correspondence between Charles Friley and John D. Jones Jr. of the Regents of the University of Wisconsin in Friley Files 9/8.

82. Ralph Himstead to C. E. Friley, 4/12/1944, Buchanan Files 8a/15, Friley Files 6/14; Friley to Himstead, 5/2/1944, Friley Files 6/14. Friley consulted Buchanan to determine how ISC should respond, if at all. Buchanan recommended that ISC should be defiant and stonewall. Buchanan to Friley, 4/24/ 1944, Buchanan Files 8a/3, Friley Files 6/14.

83. J. M. O'Neill, "Academic Freedom and the Catholics," The New Republic, 2/14/1944, 204-7. 
chanan demanded that $\mathrm{O}^{\prime}$ Neill publish "a retraction" of his statements, which "are demonstrably untrue." 84

APPROVAL of revised Pamphlet No. 5 actually had finally come on March 16, shortly before Hart and Buchanan wrote to $\mathrm{O}^{\prime}$ Neill. Attached to the revision was a "minority report," signed by Hixon. It identified treatment of technical facts in the revised pamphlet as "essentially correct," but declared that much of the analysis was mistaken on "emphasis and inference." The Special Committee further absolved itself by declaring that any appended statements must be viewed as constrained by "limitations imposed by the fact this is a revision of the former publication." 85

ISC released a publicity notice on March 17 announcing that the revised manuscript had gone to the publisher. Buchanan contacted Friley to recommend including an explanatory foreword. Buchanan also delivered the news to Brownlee, expressing appreciation for making "a substantial contribution to the economics of a very involved situation." 86 The revised manu-

84. A. G. Hart to J. M. O'Neill, 3/21/1944, Buchanan Files 8a/13; Buchanan to O'Neill, 3/27/1944, Buchanan Files 8a/17. See also Buchanan to Hart, 3/27/ 1944, Buchanan Files 8a/13; and Buchanan to Charles E. Friley, 3/27/1944, Buchanan Files 8a/3. Both Hart and Buchanan also wrote to Bruce Bliven, editor of The New Republic. Hart to Bliven, 3/21/1944, Buchanan Files 8a/17; Buchanan to Bliven, 3/27/1944, ibid.

85. R. M. Hixon et al. to R. E. Buchanan, 3/16/1944, Buchanan Files 8/11. The minority report was written by C. A. Iverson and C. Y. Cannon. C. A. Iverson and C. Y. Cannon to Ralph Hixon, 3/16/1944, Buchanan Files 8/11. In response to the minority report, Buchanan agreed that "it is highly desirable and fitting that there be complete freedom to record minority opinions and that such opinions be respected." Buchanan to Members of the Committee on Review of the Manuscript of the Revision of "Pamphlet 5," 3/21/1944, Friley Files 9/8.

86. "News Release," Information Service, Iowa State College, 3/17/1944, Buchanan Files 8/14; Buchanan to Friley, 3/17/1944, Buchanan Files 8a/2; Buchanan to Oswald Brownlee, 3/20/1944, Buchanan Files 8a/2; Buchanan to Friley, 3/20/1944, Buchanan Files 8a/3. Buchanan's foreword informed readers that the original pamphlet had contained cases of inadequate documentation, ambiguous statements, statements subject to misinterpretation, and topics inappropriately overemphasized (including "the competitive relationships of oleomargarine and butter"). The revised pamphlet explicitly was not an official publication of the Agricultural Experiment Station. R. E. Buchanan, "Foreword," in O. H. Brownlee, Wartime Farm and Food Policy Series, no. 5, rev. ed. (Ames, 1944), 1. See also Buchanan to Friley, 3/17/1944, Buchanan Files 8a/3; and Buchanan to Friley, 5/12/1944, ibid. 
script was going to be published even though dairy interests still vigorously objected to it. 87

The revised pamphlet was mailed on May 2, 1944. A corresponding news release announced that readers would find it "an enlargement of the controversial first edition." Readers of the revised pamphlet discovered citations of an ample quantity of scientific findings to make the case for nutritional equivalence between margarine and butter. The nine data tables in the text of the original pamphlet were reduced to three in the text of the revised edition (with an additional ten tables in an appendix). The subject was treated delicately, putting it that "fortified oleomargarine is nutritious and acceptable by many consumers as a spread." 88

In May 1944 the controversy was over almost as quickly as it began. Neither the AAUP nor the ACLU ever formally investigated. The ACLU's O'Neill, writing in The New Republic, criticized ISC, but officially the ACLU noted only that professors Schultz and Wilcox "were forced out because of their opinions." 89

87. Buchanan offered at least a few dairy representatives an opportunity to read the revised manuscript. See Buchanan to Clarence Nielson, 3/22/1944, Buchanan Files $8 \mathrm{a} / 8$. Representatives of the dairy group subsequently called on Friley and Buchanan to suggest that the revision not be published. Buchanan to Albert Hart, 3/27/1944, Buchanan Files 8a/8. Dairy representative Clarence Nielson appreciated that Buchanan has "no doubt done the very best job" under tough circumstances. Nielson to Buchanan, 4/1/1944, Buchanan Files 8a/8. See also Buchanan to Nielson, 4/6/1944, Buchanan Files 8a/13; Nielson to Buchanan, 4/8/1944, ibid.; and William G. Murray to Buchanan, 4/14/1944, ibid.

88. "ISC Issues Revised Version of Dairying Pamphlet," Information Service, Iowa State College, Ames, 5/2/1944, Buchanan Files 8/14. The quoted words from Brownlee are on page 39 of the revised pamphlet. Brownlee cited supportive science on the subject: A. J. Carlson, "Some Obstacles in the Path Towards an Optimum Diet I and II," Science, 4/30/1943, and 5/7/1943, 389-90, 413; Council on Foods and Nutrition, "The Comparative Nutritional Value of Butter and Oleomargarine," Journal of the American Medical Association, 8/22/ 1942, 1425-27; "A Report on Margarine," Report of the Food and Nutrition Board, National Research Council, Reprint and Circular Series, vol. 118, Aug. 1943,18 . On the contents of "A Report on Margarine," see also Margaret G. Reid, "To the Editor," Des Moines Register, 9/22/1943. Seven copies of the revised pamphlet were mailed to the Rockefeller Foundation. William G. Murray to Joseph H. Willits, 5/13/1944, Buchanan Files 8a/13 (also in folder 42, series 218S, RG 1.1, RAC-RF.

89. "Correspondence: Academic Freedom and Oleomargarine," The New Republic, 5/1/1944, 606-7; Lucille B. Milner [for Roger N. Baldwin, chairman of the ACLU], to R. E. Buchanan, Edward S. Allen, and Elizabeth Hoyt, 6/13/ 
THERE WAS FAR MORE to the controversy than simply pressure applied by special interests, the national press, and watchdog organizations. At the time of ISC's butter-margarine controversy, a canyon of difference separated how physical scientists at ISC saw research in the social sciences and how the social scientists saw their own research. Even greater than this distance between 'two cultures' was the scale of separation between two other cultures: those emphasizing research in the "public interest" versus those pressuring in favor of "special interests." The U.S. Department of Agriculture, by showing confidence in social science research at ISC, made available a great opportunity for ISC to become a national leader in social science; the school was recognized as an academic institution capable of helping meet the goal that "food will win the war." The Rockefeller Foundation joined in elevating ISC to a high echelon of academic institutions by means of an esteemed grant. But Iowa special interests demanded that restraints be placed on the definition of social science research at ISC. President Friley and others in the ISC administration agreed with Iowa special interests, at least until embarrassing national pressure forced a reversal of course. ${ }^{90}$

None of the parties could have been satisfied with the overall results. Dairy interests could only have been content with

1944; Lucille B. Milner [for Roger N. Baldwin] to R. E. Buchanan, Edward S. Allen, and Elizabeth Hoyt, 6/16/1944, Buchanan Files 8a/4. After Baldwin notified Buchanan that the ACLU had decided not to investigate, Buchanan asked Baldwin to disregard certain comments in a letter Buchanan had just mailed, in which he had tried hard to establish O'Neill's complete incompetence by exposing seemingly every possible error he had ever made in order to establish that the ACLU committee "has disqualified itself by self-evident bias." Buchanan to Baldwin, 6/12/1944, Buchanan Files 8a/4; Buchanan to Lucille B. Milner [for Roger Baldwin], 6/17/1944, ibid. See also Baldwin to Buchanan, 6/21/1944, Buchanan Files 8a/4, Schultz Files-Chicago, 29/21; and Elizabeth Hoyt to Lucille Milner [for Roger Baldwin], 6/14/1944, Buchanan Files 8a/4. The ACLU's official report provided their conclusion that although "Schultz and Wilcox were forced out because of their opinions," realistically speaking, "no legal action was possible." "In Defense of Our Liberties: A Report of the American Civil Liberties Union in the Third Year of the War" (New York, 1944), 54-55 (copy in Schultz Files-Chicago 29/21).

90. On the subject of the idea that "food will win the war," see R. K. Bliss, Director of Extension Service, "The Iowa Extension Service in The War Program," Pamphlet 49, Nov. 1942. 
complete suppression of the pamphlet. They did not anticipate that social scientists could shift society's comparative weighting of butter and margarine by adding the concern of a humanitarian cause. Many people at ISC were unsatisfied. President Friley wanted social science that would be objective and produce only raw facts, yet also support Iowa's interests. Such a goal was an untenable combination. Buchanan wanted research to serve special interests on whom the school depended for funding; but state and national media exposed the faults in such a viewwhich it appears Buchanan also came to recognize. Brownlee wanted to provide meaningful policy analysis; however, the only known recommendation ever coming from Iowa's Agricultural Extension Service was a four-page pamphlet for dairy farmers with an "8-point Dairy Program" and a narrowly targeted slogan, "Get that Extra Squirt at Every Milking." Schultz wanted social science allowing unbiased policy analysis in service to the public interest. Even though Schultz ultimately described the revised pamphlet as "no surrender," his ideal for social science was not met at ISC. Worst of all, perhaps, was that ISC's Department of Economics and Sociology was in shambles. ${ }^{91}$

Between 1943 and 1945, 16 of 26 ISC economists left the school. Still more departed over the next few years. By about 1948 the Ames School of economics had vanished. The campuswide level of discontent turned so severe that in 1947 the ISC Alumni Association pleaded with the State of Iowa Board of Education to investigate President Friley's "management practices." The board commenced to "carefully" investigate Friley in March 1947, stamping their completed findings six days after announcing the beginning of the investigation. The board declared their "utmost confidence" in Friley, and stated that this should "end the controversy so far as the board is concerned." Friley remained ISC's president for six more years. ${ }^{92}$

91. "Get that Extra Squirt at Every Milking. Iowa's 8-Point Dairy Program Information Folder," Iowa Agricultural Extension Service, ISC, 3/20/1945 (copy in "Department of Agriculture" folder, box 280, governor's files, State Historical Society of Iowa, Des Moines); T. W. Schultz to J. H. Willits, 5/12/1944, folder 42, series 218S, R.G. 1.1, RAC-RF.

92. Time Magazine reported 20 protest resignations, including 13 economists. "Bull Butter," Time, 3/27/1944, 48. Fortune also reported 20 resignations; "Will Butter Win the Peace?" Fortune Magazine, Nov. 1944, 134. Raymond R. Beneke, 
It took years for the social sciences to recover at ISC. Some departing economists followed Schultz to the University of Chicago, where a number of them reached great heights leading a "Chicago School" of economics. Two former ISC economists achieved the Nobel Prize while at Chicago, with Schultz's coming in $1979 .{ }^{93}$

Many parties share the blame for the mess at ISC. In the original Pamphlet No. 5, Brownlee did not need to declare the comparable nutritional qualities of margarine and butter by so provocatively adding that "dairy interests have been rather effective in suppressing" margarine's use. Schultz, who oversaw the pamphlet's publication, later admitted that he had a backup plan to allow him to push hard to turn social science at ISC into what he personally believed it should be. Director Buchanan perhaps persisted too long in holding to mismatched beliefs "that the results of our studies should be presented as objectively and as sincerely as possible," but "that in the last analysis the staff holds loyalty to and is responsible in a sense to the citizens of the State of Iowa inasmuch as this is a state institution." On the other side was a stubborn Iowa State Dairy Association led by Fred Larrabee, who admitted in the group's 1944 report that the major accomplishment of the organization "during the

a later economics department chair at ISC, reported that 15 social scientists resigned within a year of the controversy. "T. W. Schultz and Pamphlet No. 5: The Oleo Margarine War and Academic Freedom," Choices, Summer 1998, 4-8. According to my research, between 1943 and 1945, 16 of 26 faculty members in the Department of Economics and Sociology either left ISC or were listed as "on leave" and never returned. Iowa State College Bulletin (Ames, 1943-44), 183; Iowa State College Bulletin (Ames, 1945-46), 199. On the subject of alumni pressure for Friley's dismissal, the notice of investigation appears in the Iowa State Daily Student, 3/14/1947. Some faculty members responded with support for Friley. Des Moines Register, 3/15/1947. The press release ending the investigation was widely published in Iowa newspapers; clippings are in the Friley Files $1 / 8$.

93. Departing ISC economists who ended up at Chicago included T. W. Schultz, D. Gale Johnson, Mary Jean Bowman, William Nicholls (later to Vanderbilt University), Oswald Brownlee (later to the University of Minnesota), Margaret G. Reid, and George Stigler (who left ISC prior to the Pamphlet No. 5 controversy, with an open invitation to return to ISC). In addition to Schultz's Nobel Prize, Stigler won the prize in 1982. Also departing the scene at ISC was the Iowa Farm Economist, which ceased publication in 1946 (becoming partially absorbed in a new journal, Iowa Farm Science). 
last year had been to obtain retraction by Iowa State College of one of its pamphlets in which oleomargarine was compared favorably with butter." 94

The situation at ISC was a battle between "two cultures" on two interconnected fronts. The battle was part of a complex, nationwide conflict. One national conflict, between physical scientists and social scientists, eventually led to C. P. Snow's famous Two Cultures essay in 1960. An additional confrontation within the social sciences was between serving special interests and serving the general public interest. In fact, a number of conflicts between special interests and the public interest took place in social science during the 1940s at such schools as the University of Texas, the University of Notre Dame, and the University of Montana. At Texas, for example, four economics professors were fired for advocating policies including "socialized" ownership of public utilities and a national "Wages and Hours Act." At Notre Dame and Montana, philosophy professors got in trouble for questioning the power of big business in determining public values. ${ }^{95}$

The unique aspect of the problem in Iowa was an institutional ambiguity about the role of social science at a land-grant institution. That ambiguity created broad uncertainty about the relationship between objectivity and advocacy in social science. On opposing sides were people who wanted social research to meet standards of objectivity suitable to physical science, and people who believed that social science was a different kind of science, one needing to perform interpretive work. A related line of cleavage was between people who believed that faculty at Iowa State College could only advocate policies directly supporting Iowa interests and people who believed that the primary goal for policy research should be to help win the war. Lessons

94. Brownlee, "Putting Dairying on a War Footing," 30; T. W. Schultz to Joseph H. Willits, 9/22/1943, Schultz Files-Chicago 29/23; R. E. Buchanan to John H. Powell, 8/12/1943, Buchanan Files 8a/15; Bernard Lewis, "Academic Freedom at Iowa State, Cont'd," The New Republic, 5/15/1944, 682 (see also R. E. Buchanan to Mrs. Hiram C. Houghton Jr., 2/28/1944, Buchanan Files 8a/13).

95. Snow, Two Cultures; Ronnie Dugger, Our Invaded Universities (New York, 1974); J. M. O'Neill, "Academic Freedom and the Catholics," The New Republic, 2/14/1944, 204-7; Carla Homstad, "Two Roads Diverged: A Look Back at the Montana Study," Montana: Magazine of Western History 53 (2003), 16-29. 
learned in Iowa during 1943 and 1944 were tough ones, and they were learned at a price. But one benefit that came from the controversy was a national debate about safeguards for policyoriented social science. 